\title{
TAXA DE CRUZAMENTO NATURAL DO ALGODOEIRO HERBÁCEO NO ESTADO DE MATO GROSSO
}

\author{
Edina Regina Moresco \\ Engenheira Agrônoma
}

Orientador: Prơi. Dr. NATAL ANTONIO VELLO

Dissertação apresentada à Escola Superior de Agricultura "Luiz de Queiroz", Universidade de São Paulo, para obtenção de título de Mestre em Agronomia, Área de Concentração: Genética e Melhoramento de Plantas.

\author{
PIRACICABA \\ Estado de São Paulo - Brasil \\ Novembro - 1999
}




\section{Dados Internacionais de Catalogação na Publicação (CIP) DIVISÃo DE BIBLIOTECA E DOCUMENTAÇÃO - Campus "Luiz de Queiroz"/USP}

Moresco, Edina Regina

Taxa de cruzamento natural do algodoeiro herbáceo no Estado de Mato Grosso / Edina Regina Moresco. - - Piracicaba, 1999.

71 p. : IL.

Dissertação (mestrado) - - Escola Superior de Agricultura Luiz de Queiroz, 1999. Bibliografia.

1. Abelha 2. Alogamia 3. Algodão herbáceo 4. Cruzamento 5. Pólen 6. Polinização cruzada I. Título

CDD 633.51

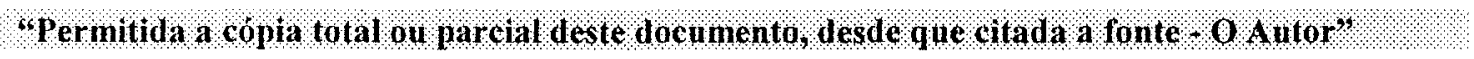




\begin{abstract}
A
Manoel Luiz Moresco,

(In memorian)

Ofereço
\end{abstract}

À minha mãe, que me deu a vida. Ao meu pai que me ensinou a viver.

Dedico. 


\section{Agradecimentos}

Nesta oportunidade agradeço a todas as pessoas que direta ou indiretamente contribuíram para o meu desenvolvimento pessoal, profissional e à elaboração desta dissertação. Em especial, agradeço:

A DEUS, "pois tudo posso com aquele que me fortalece".

Ao conselho Nacional de Desenvolvimento Científico e Tecnológico - CNPq, pela concessão da bolsa de estudos.

Ao Professor Dr. Natal Antonio Vello, pela orientação, e aos demais professores da ESALQ/USP pelos conhecimentos adquiridos.

À EMBRAPA-ALGODÃO, pela colaboração e orientação decisiva, especialmente ao Dr. Elêusio Curvêlo Freire e Francisco Farias.

Ao Dr. Imre Lahos Griddi-Papp pelo auxílio precioso na elaboração deste projeto.

A Dario Minoru Hiromoto pela confiança e apoio em todas as situações.

À toda equipe da Fundação Mato Grosso - pelo apoio incondicional.

Aos amigos da equipe do algodão, Paulo H. Aguiar, Marcelo F. Marques, Márcio C. da Costa, Ítalo da S. Martins, Adontino C. de Almeida, Cirson P. da Silva, pelo convívio e desenvolvimento deste projeto.

A Cláudio Segatelli e demais funcionários da ESALQ pela condução do experimento em Piracicaba.

Aos demais funcionários que estiveram diretamente envolvidos na elaboração desta pesquisa, cujos nomes não menciono, que, por vezes, são personagens nestas páginas de não-fiç̧ão, para quem, certamente, "qualquer semelhança não terá sido mera coincidência".

Ao professor Dr. Décio Barbin e aos alunos do departamento de Estatística Jeanete e Arley pela orientação nas análises estatísticas.

Aos colegas do departamento de genética e melhoramento de plantas: Fábio Pandinni, Andréa Mittelmann, Bethânia L. Rocha, Maria I. Zuchi, Cláudio 
Tsutsumi, Vanoli Fronza, MauroIsrael de M. Rocha, Alexandre S. G. Coelho, Gustavo J. M. Brito, pela convivência e amizade.

Agradecimento especial às parceiras: Taysa G. Fonseca, Ana Lídia V. Bonnato, Roseli F. Caseiro, Elizabethy K. Takahashi, Monalisa S. Carneiro, Patrícia F. Cardoso, pelo companheirismo e bom humor constantes.

A Heloísa C. de P. Breseghello, Patrícia Kompier, Marion Kompier pela amizade que venceu o tempo e a distância.

A meus pais, Euclides e Santina, pelos preciosos valores com os quais pautaram a minha vida; e a meus irmãos - Flávio, Alessandra e Gustavo companheiros de jornada, que respeitaram sempre todas as minhas extravagâncias. Às sobrinhas Bruna e Patrícia, verdadeiros anjinhos sem asas.

A Claudio Takeda, que teve fé em mim e no meu trabalho.

Graças à vida e obrigada à Inteligência Superior pela inspiração, saúde e satisfação pessoal na realização deste trabalho.

"O homem não está sozinho, não vive sozinho e só não faz nada."

"Nenhum homem é uma ilha."

Acredito nesta frase e tenho a certeza de que sem você, que emprestou seu talento, sua dedicação, seu profissionalismo, sua amizade, suas criticas, suas orações, não teriamos colhido este fruto. Sinto-me privilegiada por estar rodeada por pessoas que, como você, me ajudaram a concretizar este nosso trabalho. Peço que a luz que nos iluminou continue a brilhar sobre nós, para podermos juntos, gerar outros belos projetos. 


\section{SUMÁRIO}

Página

1. INTRODUÇÃO

2. REVISÃO BIBLIOGRÁFICA

2.1. Mecanismos de polinização …………………………………………………........ 05

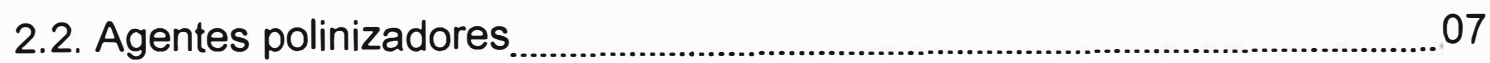

2.3. Cruzamento natural do algodoeiro herbáceo .................................................. 09

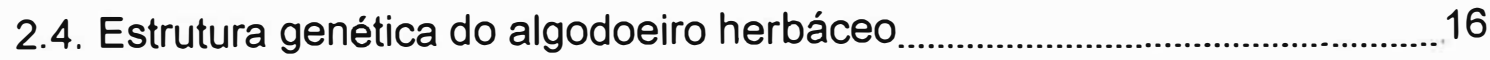

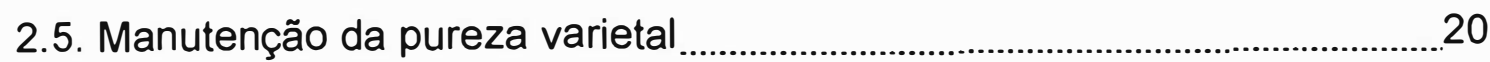

3. MATERIAL E MÉTODOS

3.1. Determinação da taxa de cruzamento natural ...............................................2

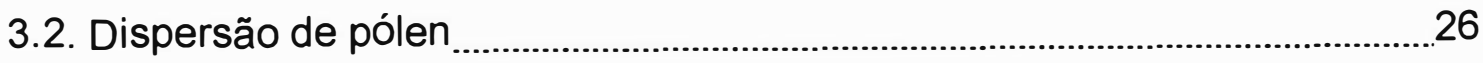

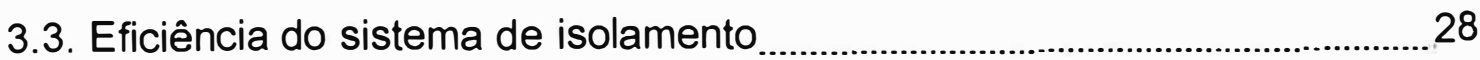

3.4. Avaliação da população de plantas sem glândulas ...........................................

3.5. Avaliação das amostras coletadas a campo

3.6. Análise estatística

3.6.1. Avaliação da distância de dispersão de pólen …...........................................33

3.7. Identificação dos agentes polinizadores............................................................ 34

4. RESULTADOS E DISCUSSÃO

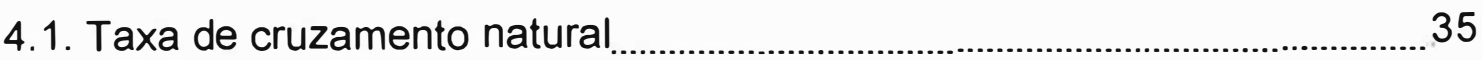

4.2. Distância e direção da dispersão de pólen ........................................................ 45

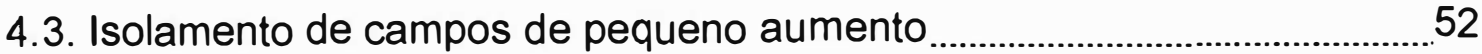

4.4. Identificação de insetos polinizadores ..............................................................5

4.5. Avaliação da população plantas sem glândulas ............................................... 57

5. CONCLUSÕES

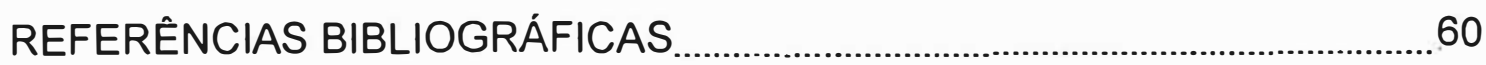

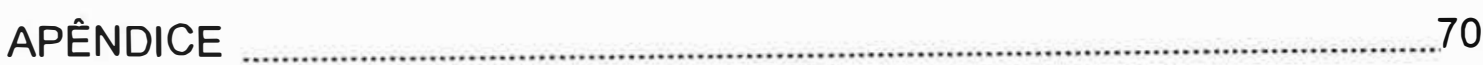




\title{
TAXA DE CRUZAMENTO NATURAL DO ALGODOEIRO HERBÁCEO NO ESTADO DE MATO GROSSO
}

\author{
Autora: EDINA REGINA MORESCO \\ Orientador: NATAL ANTONIO VELLO
}

\section{RESUMO}

Este trabalho foi elaborado com o objetivo de determinar a taxa de cruzamento e a dispersão de pólen do algodoeiro herbáceo no Estado de Mato Grosso. A taxa de cruzamento foi determinada através de marcadores que controlam a presença e ausência de glândulas nas plantas. Plantas e sementes homozigóticas duplo-recessivas $\left(\mathrm{gl}_{2} \mathrm{gl}_{2} \mathrm{gl}_{3} \mathrm{gl} \mathrm{l}_{3}\right)$ não apresentam glândulas. No ano agrícola 97/98, em Rondonópolis, as plantas marcadas foram semeadas em fileiras nas bordaduras de experimentos com algodoeiro e a avaliação foi efetuada em duas épocas de colheita; na primeira colheita obteve-se $7,40 \%$ de cruzamentos e na segunda $20,68 \%$. O maior valor encontrado no período mais tardio, conforme o esperado, deveu-se a maior atividade de insetos polinizadores neste período. Através do descarte das sementes coletadas na segunda colheita, pôde-se diminuir a mistura varietal em $55,04 \%$. No ano agrícola de 98/99 foram feitas avaliações em seis localidades; as plantas duplorecessivas foram dispersas na área experimental; as sementes coletadas das mesmas foram avaliadas para a presença e ausência de glândulas. Os locais avaliados apresentaram os seguintes valores para a taxa de cruzamento: Pedra 
Preta I (68,83\%), Pedra Preta II (50,44\%), Serra da Petrovina II (46,85\%), Serra da Petrovina I (44,98\%), Primavera do Leste $(8,42 \%)$ e Campo Verde $(6,54 \%)$. A grande discrepância entre os valores encontrados é resultado da ação dos insetos polinizadores presentes em cada região, já que a polinização natural do algodoeiro é efetuada essencialmente por insetos. Neste trabalho, os insetos responsáveis pelo cruzamento foram caracterizados como sendo abelhas (Apis mellifera). O estudo da dispersão e direção de pólen foi efetuado através de um campo de $20 \times 20$ metros contendo plantas com genes recessivos para 0 caráter marcador; duas plantas contendo alelos dominantes $\left(\mathrm{Gl}_{2} \mathrm{Gl}_{2} \mathrm{Gl}_{3} \mathrm{Gl}_{3}\right)$ localizada no centro do mesmo, serviu como fonte de pólen. A regressão traçada para taxa de cruzamento apresentou $r^{2}=98,52 \%$ com valores variando de $15,75 \%$ (nas fileiras vizinhas ao ponto de dispersão) e 1,04\% (a dez metros de distanciamento do mesmo). A taxa de visitação por insetos polinizadores também apresentou decréscimo similar $\left(r^{2}=89,63 \%\right)$ e valores variando de $48 \%$ (nas fileiras vizinhas ao centro de dispersão de pólen) a 16,7\% (a dez metros de distanciamento do centro de dispersão de pólen). Os dados obtidos demonstraram que distâncias superiores a dez metros, sem a utilização de barreiras vegetais, minimizam a contaminação entre campos vizinhos. A taxa de cruzamento apresentou diferenças significativas entre as direções cardeais (Norte, Sul, Leste e Oeste). A região Norte apresentou a maior concentração tanto da taxa de cruzamento quanto do percentual de plantas visitadas, determinando que a população de insetos polinizadores apresentava maior atividade nesta porção da área. Deste modo, pôde-se concluir que o algodão é uma espécie de sistema reprodutivo misto, sendo a taxa de cruzamento natural influenciada pela população e ação de insetos polinizadores (abelhas). 


\title{
NATURAL CROSSING OF UPLAND COTTON IN THE MATO GROSSO STATE
}

\author{
Author: EDINA REGINA MORESCO \\ Advisor: NATAL ANTONIO VELLO
}

\section{SUMMARY}

This research aimed to determine the outcrossing rate and the dispersion of pollen of the upland cotton in the Savannah (cerrado) of the Mato Grosso State, Brazil. The outcrossing rate was determined through markers that control the presence and absence of glands in the plants. Plants and seeds double-recessive homozygous ( $\mathrm{g} / 2 \mathrm{~g} / 2 \mathrm{~g} / 3 \mathrm{~g} / 3$ ) are glandless. In the agricultural season 97/98, in Rondonópolis, the marked plants were sowed in arrays in the borders of the experiments with cotton and the evaluation was made in two harvest times; the outcrossing rate were $7.40 \%$ and $20.68 \%$ in the first and second harvest, respectively. The largest value found in the latest period, as expected, was due the largest activity of pollinators insects. Through the discard of the seeds collected in the second harvest, it could reduce the varietal mixture in $55.04 \%$. In the agricultural season of 98/99 the evaluations were made in six localities; the doublerecessive plants were dispersed in the experimental area; the collected seeds of there plants were evaluated for the presence and absence of glands. There was observed large variation among localities for outcrossing rate: Pedra Preta I (68.83\%), Pedra Preta II (50.44\%), Serra da Petrovina II (46.85\%), Serra da Petrovina I (44.98\%), Primavera do Leste $(8.42 \%)$ and Campo Verde $(6.54 \%)$. The 
activity and population of pollinator insects present were associated with the variation in outcrossing rates across localities. In this work, the responsible insect for the outcrossing were characterized as being bees (Apis mellifera). The study of the dispersion and pollen direction was made through a field of $20 \times 20$ meters containing plants with recessive genes for the character marker; a plant containing dominant alleles $\left(\mathrm{Gl}_{2} \mathrm{Gl}_{2} \mathrm{Gl}_{3} \mathrm{Gl}_{3}\right)$ located in the center of the field, served as pollen source. The regression curve $\left(r^{2}=.958\right)$ for outcrossing rate varied from $1.04 \%$ (at tem meters of the pollen source) to $15.75 \%$ (at neighbor plants of the pollen source). The visitation rate of bees had a regression curve $\left(r^{2}=.896\right)$ varying from $16.7 \%$ (at tem meters of the pollen source) to $48.0 \%$ (at neighbor plants of the pollen source), similarly to the curve for outcrossing. Then, minimum distances of tem meters, without vegetable barriers, were enough to prevent or minimize the contamination among fields. The crossing rate presented significant differences among cardinal directions; the North area presented the largest value of crossing and visited plants, probably, caused by the highest activity of the bees. In conclusion, the upland cotton showed a mixed reproductive system in Brazilian Savannah; being the rate of natural crossing much influenced by the population and activity level of bees. 


\section{INTRODUÇÃO}

Algodão é o nome comum de uma série de espécies úteis do gênero Gossypium que apresentam fibras fiáveis, presentes no tegumento de suas sementes. O Gênero Gossypium possuí 52 espécies que pertencem a oito diferentes genomas ( $A, B, C, D, E, F, G$ e AD). $O$ algodoeiro é ainda identificado por dois tipos distintos: herbáceo (variedades anuais, mais produtivas, predominando a produção de fibras de comprimento médio compreendido entre 30-32 $\mathrm{mm}$ ) e arbóreo (variedades semi-perenes, xerófita, de menor produtividade e que produz fibra longa e extra longa, acima de $34 \mathrm{~mm}$ ).

Todos os algodoeiros primitivos são arbustivos, com hábito perene. Os algodoeiros anuais, de ciclo curto, foram selecionados pelo homem. Existem representantes de algodoeiros arbóreos em todas as espécies. No Brasil, encontra-se o mocó, da espécie G. hirsutum, o rim-de-boi e o quebradinho da espécie G. barbadense. Algodoeiros herbáceos foram selecionados nas espécies G. herbaceum, G. arboreum, G. barbadense e G. hirsutum. Esta última espécie engloba o maior número de variedades herbáceas selecionadas.

A produção mundial de algodão está baseada na produção de fibras, oriunda de quatro espécies: G. herbaceum L., G. arboreum L. (espécies diplóides e nativas do Velho Mundo), G. barbadense L., e G. hirsutum L. (espécies tetraplóides originárias do Novo Mundo).

A espécie G. herbaceum, importante no início do desenvolvimento da cultura, hoje se encontra restrita apenas para uso local em áreas secas da África e Ásia. A espécie G. arboreum ainda hoje ocupa grandes áreas na Índia. 
Atualmente, estas duas espécies contribuem com menos de $4 \%$ do total mundial de fibras de algodão atualmente produzidos. A espécie $G$. barbadense L., conhecida por vários nomes como Egípcio e Pima, produz fibras extralongas (com mais de $35 \mathrm{~mm}$ de comprimento), geralmente usadas na confecção de tecidos de luxo, contribuí com $8 \%$ da produção mundial. A espécie $G$. hirsutum L., conhecido comumente como "Upland", produz fibras de média a longa $(25,4$ a $34,9 \mathrm{~mm})$ e contribui com aproximadamente $90 \%$ da produção mundial de fibras no mundo (Kohel \& Lewis, 1984).

As espécies mais importantes do ponto de vista econômico são $G$. hirsutum L. e G. barbadense L. Ambas são espécies alotetraplóides, originadas a partir de hibridização natural entre espécies de dois diferentes grupos genômicos. A espécie G. hirsutum é originária da América Central e corresponde às variedades mais cultivadas atualmente: variedades americanas (Upland), variedades nacionais e vários genótipos selvagens ou primitivos, como marie-galante (algodão mocó), punctatum, morrrili, yuatense, palmeri e richmondi. A espécie $G$. barbadense é cultivada em áreas quentes de todo mundo; característico por apresentar fibra longa, alguns tipos representativos desta espécie são o Sea Island, nos Estados Unidos, o Rim-de-boi no Brasil e o Tanguis no Peru (Gridi-Papp et al., 1992). Detalhes sobre o grupo genômico, nível de ploidia e origem podem ser observados na tabela abaixo.

Tabela 1 Espécies cultivadas do gênero Gossypium.

\begin{tabular}{lccl}
\hline Espécies & Genoma & N. haplóide & \multicolumn{1}{c}{ Origem } \\
\hline G. herbaceum $\mathrm{L}$. & $\mathrm{A}_{1}$ & 13 & África, Ásia \\
G. arboreum $\mathrm{L}$. & $\mathrm{A}_{2}$ & 13 & África, Ásia \\
G. hirsutum $\mathrm{L}$. & $(\mathrm{AD})_{1}$ & 26 & América Central \\
G. barbadense L. & $(\mathrm{AD})_{2}$ & 26 & América do Sul \\
\hline
\end{tabular}


O algodoeiro apesar de possuir somente flores hermafroditas, apresenta sementes oriundas de autofecundação e também a partir de cruzamentos variáveis (Stephens \& Finkner, 1953). Os métodos de melhoramento utilizados no desenvolvimento de uma nova variedade dependem, em parte, do processo de reprodução da espécie. Diversos autores classificam as espécies cultivadas que se reproduzem por via sexual em três grupos: autógamas (< $5 \%$ de cruzamento), alógamas ( $>95 \%$ de cruzamento) e sistema reprodutivo misto (entre 5 e $95 \%$ de cruzamento).

O algodão herbáceo ( $G$. hirsutum) é usualmente referido como uma espécie de sistema misto de reprodução, apesar de alguns melhoristas tratá-lo como espécie autógama, completamente autopolinizada, exceto por polinização acidental efetuada por insetos. O cruzamento entre plantas tem sido referido como "cruzamento natural", e é considerado detrimental devido à introdução de pólen exógeno na progênie. O impacto desta introdução na produção de linhagens e variedades tem sido pouco considerado. Existem algumas técnicas que podem ser utilizadas para isolar um campo do outro e que permitem o desenvolvimento de estruturas com sementes viáveis e com sua pureza varietal garantida (Stephens, 1956).

A determinação da taxa de cruzamento natural em diferentes locais é importante para determinar os métodos de melhoramento a serem empregados e para dimensionar barreiras vegetais necessárias ao isolamento de populações. A necessidade de determinar e delimitar os níveis de autofecundação e cruzamento é fator primordial para o entendimento dos processos evolutivos e melhor aplicação das estratégias de melhoramento, já que os métodos de melhoramento das espécies autógamas, alógamas e mistas diferem entre si.

Desta forma, a determinação da taxa de cruzamento do algodão herbáceo (G. hirsutum) no cerrado de Mato Grosso, possibilitará a adoção de 
metodologias compativeis com as condições da região. Os principais objetivos deste trabalho foram:

a) determinar a taxa de cruzamento natural em diferentes locais do cérrado de Mato Grosso;

b) determinar a distância e direção da dispersão de pólen;

c) verificar a presença de agentes polinizadores. 


\section{REVISÃO BIBLIOGRÁFICA}

\subsection{Mecanismos de polinização}

O algodoeiro herbáceo (G. hirsutum) possui flores completas, grandes e normalmente não mais de três abrem por dia, por planta. No estágio de botão floral, a flor é protegida por um epicálice de três ou quatro brácteas largas as quais persistem quando a flor abre. As pétalas são em número de cinco, com cores variáveis de acordo com a espécie. As anteras são ligadas através de um filete a uma coluna estaminal que envolve o estilete até a base do estigma (Figura 1). As anteras, ao sofrerem deiscência, deixam grãos-de-pólen bem próximos e até mesmo em contato com o estigma. O pólen é disperso pelas anteras logo depois da flor abrir, permanecendo viável por aproximadamente 12 horas. O ovário superior possui três das cinco unidades carpelares, contendo cada uma vários óvulos. O longo estilo é projetado através do topo do tubo estaminal onde este se divide em três a cinco estigmas de acordo com o número de carpelos (Coobley, 1956).

As flores abrem no início da manhã e fecham ao entardecer do mesmo dia, não mais se abrindo. A viabilidade do pólen decresce gradualmente após as 09:00 h, embora já tenham sido encontradas evidências de que o pólen permanece hábil para fertilizar $86 \%$ das flores após as 17:00 horas no dia da antese, sendo ainda observado $38 \%$ de flores fecundadas, quando a polinização ocorre às 8:00 horas da manhã seguinte. O estigma permanece ainda receptivo pelo mesmo tempo em que o pólen está sendo disperso, entretanto na manhã seguinte somente $8 \%$ permanece viável. A fertilização ocorre 30 horas depois da polinização (Free, 1993). 

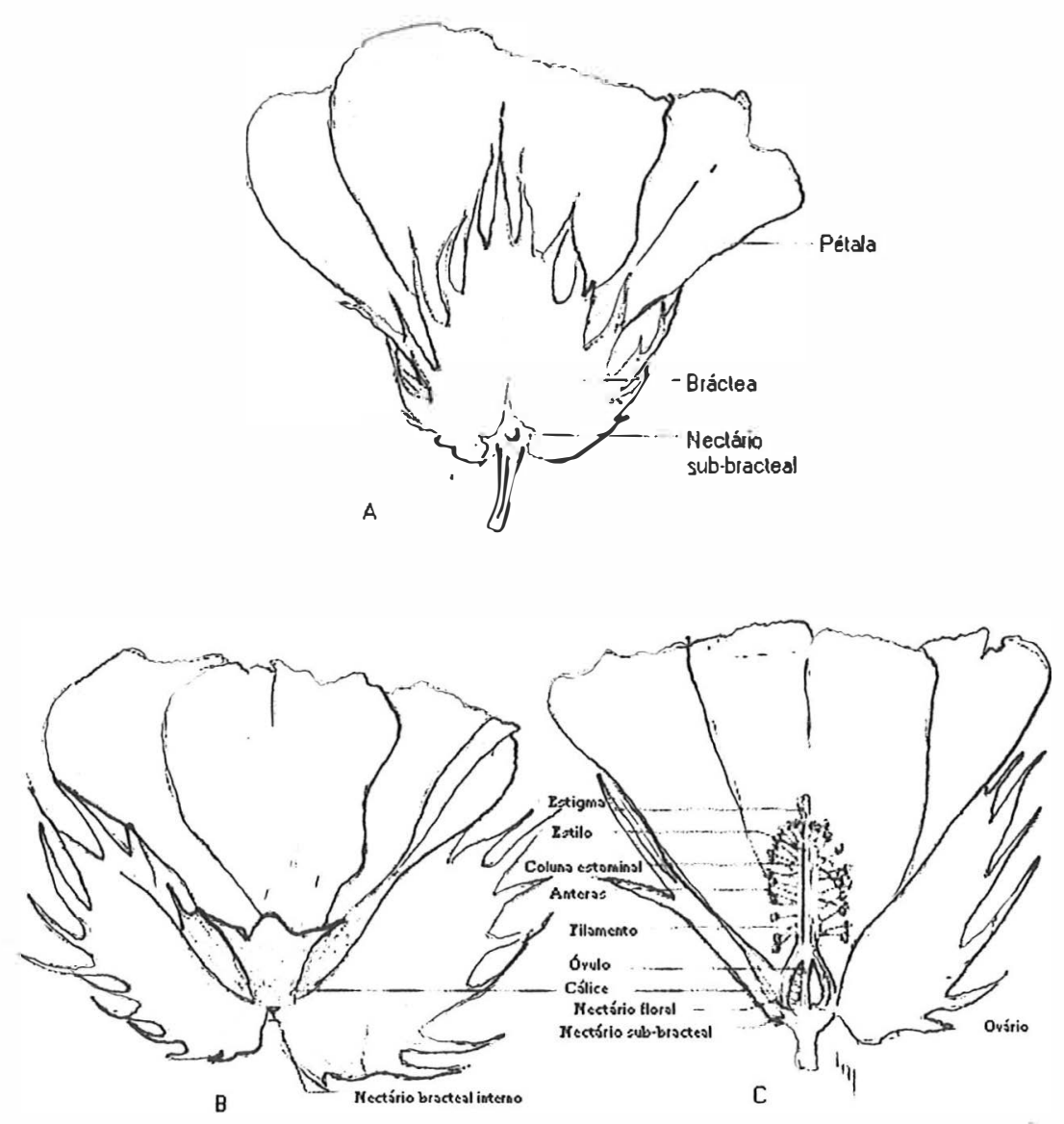

Figura 1 Flor de algodão. (A) vista lateral, mostrando um dos três nectários sub-bracteais; (B) brácteas afastadas para mostrar um dos três nectários do interior das brácteas; (C) seção longitudinal, demonstrando as estruturas reprodutivas. (McGregor, 1976).

O grão de pólen do algodoeiro é grande, pegajoso, e se aglomera em grumos, não sendo, portanto facilmente levado pelo vento. Nas horas mais quentes do dia, o pólen seco pode ser levado pelo vento, porém já inviável (Collings \& Wallace, 1931).

O algodoeiro possui ainda cinco conjuntos de nectários, um floral e quatro extraflorais. O nectário floral consiste de um anel na parte interna do cálice. Os nectários extraflorais consistem em: (a) três nectários triangulares contornando o cálice próximo à base; (b) três nectários no pedicelo de cada flor 
abaixo de cada bráctea do epicálice; (c) um nectário na parte basal de cada folha; (d) nectários unipapilados no pedúnculo floral e haste de folhas jovens. A secreção de néctar é favorecida em temperaturas entre 25 e $35{ }^{\circ} \mathrm{C}$. Apesar das diferenças existentes entre variedades, em geral, todos os nectários da planta produzem néctar numa concentração de aproximadamente $20 \%$ do volume secretado. Entretanto a evaporação nos nectários extraflorais é muito maior do que a do nectário floral, tendo desta forma um rápido aumento na concentração de açúcar, que pode variar de 60 a $82 \%$ comparada com 20 a 54\% do nectário floral (Parks, 1921; Grout, 1955).

Enquanto o nectário floral secreta néctar somente no dia em que a flor se abre, os nectários extraflorais secretam por alguns dias. O néctar que permanece de um dia para o outro auxilia no aumento da concentração de açúcar. Consequentemente, a presença de nectários extraflorais serve como um importante atrativo para o aumento da população de abelhas (Grout, 1955; McGregor, 1959). Apesar de já se ter observado que as abelhas preferem visitar os nectários florais, os nectários extraflorais são importantes para manter as abelhas na cultura antes das flores se abrirem (Moffett et al., 1979).

\subsection{Agentes polinizadores}

A polinização natural do algodoeiro é efetuada por insetos. O vento, que em muitas culturas é importante agente de polinização, no caso específico do algodão definitivamente não o é, e sua velocidade e direção não apresentam influência sobre os valores encontrados. Quando as flores de algodão foram emasculadas e expostas ao vento, mas não a insetos, poucas estruturas frutiferas foram formadas, comparativamente com flores emasculadas que foram visitadas por abelhas (Afzal \& Khan, 1950; Thies, 1953).

$\mathrm{O}$ algodão é visitado por várias espécies de insetos. Na Índia, já foram observadas 41 espécies de 23 famílias de sete ordens visitando o algodoeiro. 
Entretanto, alguns dos insetos não visitam os nectários florais e alguns destes sequer tocam as partes sexuais da planta (Free, 1993). No Arizona, EUA, 90 espécies de insetos foram coletadas de flores de algodão (Moffet et al., 1976c, 1979) e no Texas, EUA, 35 espécies de abelhas (Moffett et al., 1976a, 1976b). Somente abelhas e vespas carregam uma quantidade considerável de pólen. De um modo geral, os insetos polinizadores de maior importância em várias partes de mundo são: Apis mellifera, A. dorsata, A. florea, A. cerrana, Melissodes spp., Halictus spp., Bombus spp., Anthophora confusa, Elis thoracica e Scolia spp.

$\mathrm{Na}$ Índia foi constatada uma média de 47 insetos visitando cada flor de algodão por dia. As abelhas, Apis dorsata, Apis cerana e Apis florea são importantes polinizadores e visitam mais flores por minuto e por viagem do que as vespas, Scolia avreipennis e Elis thoracica. Todavia a abundância de vespas e a sua grande tendência para visitar flores em condições adversas de temperatura e precipitação, mantém estas espécies como importantes polinizadores da cultura (Free, 1993).

No Brasil, os insetos polinizadores freqüentemente encontrados associados à cultura são os apídeos. Cuja maior atividade está entre 6 h 30 min e 12 h 30 min (Silva et al., 1973).

Apesar de outros insetos poderem ser polinizadores mais eficientes, a abelha (Apis mellifera), devido a sua abundância, é o polinizador mais importante de algodão em algumas partes do mundo, sendo desta forma o mais estudado. As abelhas trabalham das 7:00 às 20:00 h diariamente, mas são mais ativas próximas do meio-dia (Free, 1993), quando a quantidade e concentração de néctar é maior, e a partir deste fato geralmente é suposto que sua performance como polinizador é baixa durante o entardecer. Muitas abelhas preferem visitar os nectários extraflorais do que visitar as flores (Moffett et al., 1979). Entretanto, foi demonstrado que a proporção de abelhas visitando os nectários floral e extraflorais diferiu com os genótipos de algodão (Loper, 1986). Os nectários extraflorais são importantes para atrair abelhas para a cultura, 
especialmente no início da manhã, quando poucos ou nenhum nectário floral está presente (Loper \& Martin, 1984).

As abelhas melíferas podem voar até $13,6 \mathrm{Km}$ à procura de alimento, quando a colméia é colocada em local onde ele é escasso. Elas estabelecem hábitos definidos de alimentação, tendendo a retornar à mesma porção de área, em sucessivos dias, mesmo havendo outras áreas da mesma planta mais próxima da colméia (Free, 1993). Quando um inseto entra em um campo, a primeira flor que ele visita o proverá de uma carga inicial de pólen. Sua procura por alimento obedece a vôos curtos, normalmente no sentido da próxima flor visível. A máxima transferência de pólen ocorreria para a segunda flor visitada,

ou seja, logo após o inseto ter recebido sua carga inicial de pólen. A sua distribuição a partir de um ponto é um procedimento simples de "colocar e tirar". Cada parada do inseto em uma flor resulta numa certa diluição da carga anterior e uma recarga de pólen da última flor visitada. Se um inseto sai de um campo e entra em outro, no princípio irá promover maior intercruzamento, que gradativamente irá diminuindo, pela diluição da carga inicial de pólen; por outro lado, o intracruzamento irá aumentando, em função de novas e consecutivas recargas (Simpson \& Duncan, 1956).

\subsection{Cruzamento natural do algodoeiro herbáceo}

Cruzamento natural é o percentual de polinização cruzada efetuada por insetos que pode ser detectado nas linhagens melhoradas (McGregor, 1976). Fryxell (1967), definiu cruzamento natural como aquele que ocorre entre indivíduos de uma população. Tanto o cruzamento intra- como o interpopulacional ocorrem, mas a distinção entre estes não é claramente detectável, a não ser através de marcadores morfológicos ou genéticos presentes na linhagem parental (Simpson, 1954). Por esta razão, a extensão do cruzamento natural do algodoeiro tem sido consistentemente subestimada por alguns melhoristas, quando é observado somente o movimento de insetos e não é estimado o fluxo de pólen. 
Vários melhoristas têm reportado a porcentagem de cruzamento natural em área de condução de experimentos (Tabela 2) e comentado o seu detrimento para a criação de novas variedades (McGregor, 1976). Balls ${ }^{1}$, citado por Free (1993), reportou $13,3 \%$ de cruzamento natural no algodoeiro no Egito, e propôs $\mathrm{o}$ isolamento de plantas através de telados. Entretanto, observou que algumas linhagens quando submetidas a este tratamento abortavam os frutos. Meredith \& Bridge (1973), também reportaram 5 a 10\% de cruzamento natural entre variedades de algodão produzidas em fileiras adjacentes nos Estados Unidos e concluiu que uma prevenção de cruzamento requer isolamento do algodoeiro por 8 a $16 \mathrm{Km}$ de outros campos.

A ocorrência de cruzamento entre campos é uma das maiores causas de descarte de variedades de algodoeiro no período de seleção (Cook, 1921). Entretanto, manter os estoques de sementes das linhagens superiores certamente é preferivel do que criar novas linhagens. Para manter bons estoques de sementes é necessário completo isolamento de outras variedades para prevenir a contaminação por cruzamento natural (Cook, 1932). Em estudos para definição da distância segura foi considerada suficiente $1,6 \mathrm{Km}$ de distância entre campos vizinhos (Peebles, 1942).

Indicações das distâncias de isolamento entre campos de produção de sementes de diferentes variedades, têm sido obtido através de: (a) semeadura de uma planta geneticamente marcada no centro de um bloco de outra variedade e medida do percentual de cruzamento em diferentes direções de distâncias da planta marcada; ou, (b) encontrar o percentual de contaminação que ocorre a diferentes distâncias entre duas variedades adjacentes; ou, (c) determinar a taxa de cruzamento entre blocos de diferentes variedades separadas por diferentes distâncias (Free, 1993).

\footnotetext{
${ }^{1}$ BALLS, W. L. Natural crossing in Egyptian cotton. Yearbook of Khedivial Agricultural Society, v. 1, n. 1, p. 12-
} $17,1912$. 
Tabela 2 Taxas de polinização cruzada do algodoeiro enoontradas em algumas regiōes

\begin{tabular}{|c|c|c|c|}
\hline AUTOR & ANO & LOCAL & $\%$ \\
\hline \multirow[t]{2}{*}{ Balls $^{1}$ (citado por Free, 1993) } & 1909 & Egito & $5-10$ \\
\hline & 1912 & Egito & $5-35$ \\
\hline Kearney $^{2}$ (citado por Free, 1973) & 1923 & E.U.A. & $1-40$ \\
\hline Stroman \& Mahoney & 1925 & E.U.A. & $2-19$ \\
\hline Brown & 1927 & E.U.A. & $2-19$ \\
\hline Ware $^{3}$ (citado por McGregor, 1976) & 1927 & E.U.A. & $1-40$ \\
\hline Kottur $^{4}$ (citado por McGregor, 1976) & 1930 & Índia & $2-6$ \\
\hline Fikry & 1931 & Egito & 4,1 \\
\hline Yu \& Hsieh & 1937 & China & $0,28-5,6$ \\
\hline `Zunino & 1949 & Argentina & $10-12$ \\
\hline Afzal \& Khan & 1950 & $\begin{array}{l}\text { Pakistão } \\
\text { Índia }\end{array}$ & $\begin{array}{c}2 \\
2-6\end{array}$ \\
\hline Thies & 1953 & Oklahoma & $25-30$ \\
\hline Knight \& Rose & 1954 & Sudão & $<0,2$ \\
\hline \multirow[t]{3}{*}{ Simpson } & 1954 & Texas & $10 \%$ \\
\hline & & Southeastern U.S.A. & 39 \\
\hline & & Mississippi & 28 \\
\hline Simpson \& Duncan & 1956 & Tenesse & 47 \\
\hline Cross \& Richmond & 1959 & Texas & 7 \\
\hline Berninger & 1960 & Tiken - Chade & 50 \\
\hline Buffet & 1960 & Bebedjia - Chade & 70 \\
\hline Richmond & 1962 & Texas & $24-40$ \\
\hline \multirow[t]{2}{*}{ Cavaleri \& Gridi-Papp } & 1963 & São Paulo & 6 a 41 \\
\hline & & Campinas & 33 \\
\hline Sappenfield & 1963 & Missouri & 13,6 \\
\hline Thompson & 1966 & $\begin{array}{c}\text { North Western } \\
\text { Austrália }\end{array}$ & 1,33 \\
\hline Mungomery \& Glassop & 1969 & Austrália & 4,2 \\
\hline Mangueira & 1971 & Serra Talhada-PE & 1 a 100 \\
\hline Galal et all. & 1972 & Egito & 3,0 \\
\hline Meredith \& Bridge & 1973 & Mississippi & 2 \\
\hline Silva et all. & 1973 & Ceará & 55 \\
\hline Castro & 1975 & Sete Lagoas & 32 \\
\hline Elfawal et all. & 1976 & Egito & $0,21-3,54$ \\
\hline Lee & 1980 & Califórnia e Texas & 15 \\
\hline Penna et all. & 1991 & Uberaba & 25 \\
\hline Queiroga et all. & 1993 & Patos - PB & 3 a 97 \\
\hline Resende \& Falieri & 1995 & Porteirinha - MG & 10,11 \\
\hline
\end{tabular}

${ }^{2}$ KEARNEY, T. H. Self-fertilizacion and cross-fertilisacion in Pima cotton. Washington: USDA, 1923 15p. (USDA. Bulletin, . 1164)

${ }^{3}$ Ware, J. O. Cotton spacing. Arkansas: Arkansas Agricultural Experimental Station, 1927, 80p. (Akansas Agricultural Experimental Extation. Bulletin 220).

${ }^{4}$ Kottur, G. L. Cross-fertilization and sterility in cotton. Agricultural Journal of India, v. 16, n. 1, p. 52 59,1921 . 
A presença e a magnitude do cruzamento natural no algodoeiro são associadas geralmente aos seguintes fatores: (a) o pólen do algodoeiro é relativamente pesado e o vento não é um agente de sua dispersão; (b) a maior parte do cruzamento é determinada pelo número de insetos polinizadores em relação ao número de flores na área; e (c) o hábito de florescimento da variedade, (d) abundância de pólen, (e) a localização dos campos em relação ao "habitat" dos insetos, (f) o período de floração de outras plantas atrativas para os insetos polinizadores, (g) a distância entre variedades distintas, (h) a topografia, (i) as barreiras vegetais e (j) outros fatores ambientais, climáticos e bióticos (Simpson, 1956).

Vários fatores podem influenciar a freqüência de cruzamento natural:

a) Método usado na determinação da taxa de cruzamento natural

Alguns autores, no mesmo local e ano, encontraram valores diferentes para a taxa de cruzamento natural, ao usarem metodologias diferentes de avaliação (Afzal \& Khan, 1950; Cavaleri \& Gridi-Papp, 1963; Free, 1993).

b) Tipo de marcador utilizado

Alguns caracteres usados como marcadores são: "planta vermelha", condicionado pelo gene $\mathrm{R}_{1}$ (Allard, 1910); "frutos sem glândula", condicionado pelo gene $\mathrm{gl}_{1}$, responsável por plantas sem glândulas internas no hipocótilo, caule, pecíolo e maçãs; "plantas sem glândulas", condicionado pelos genes $\mathrm{gl}_{2}$ e $\mathrm{gl}_{3}$ responsáveis pela ausência de glândulas internas em toda a planta (McMichael, 1954).

c) Variedade

Dependendo da espécie e da variedade utilizada, obtêm-se respostas diferentes para a taxa de cruzamento natural. Vários autores têm demonstrado esse comportamento diferencial (Stephens 
\& Finkner, 1953; Turner, 1953; Finkner, 1954; Simpson, 1954; Simpson \& Duncan, 1956).

d) Insetos polinizadores

A população dos insetos polinizadores é determinante na ocorrência de cruzamento em espécies como o algodoeiro (Free, 1993).

e) Aplicação de inseticidas

Afeta a polinização cruzada, pela ação repelente ou através de mortalidade nas populações de insetos (Thompson, 1966; Meredith \& Bridge, 1973).

f) Fatores ligados ao clima

A média de temperatura e a precipitação pluviométrica durante 0 ano e durante o dia são determinantes na movimentação dos insetos polinizadores (Thies, 1953; Richards, 1997).

g) Fatores ecoambientais

A diversidade e a densidade de espécies vegetais, assim como seu distanciamento da cultura, tem grande interferência sobre a amplitude da distribuição de pólen por insetos (Richards, 1997). A ocorrência de desmatamentos e queimadas, afetam sobremaneira a população de insetos (Meredith \& Bridge, 1973).

h) Tamanho da população amostrada

O tamanho da amostra de descendentes também interfere na determinação da taxa de cruzamento natural. Para o algodoeiro, 200 sementes parece ser o número mais apropriado (Simpson, 1954).

i) Tipo de barreira utilizada

O tipo de barreira utilizada para 0 isolamento dos campos de produção, dependendo da cultura utilizada, determina uma maior ou 
menor eficiência na contenção dos insetos polinizadores. As culturas mais utilizadas são o algodoeiro, milho, crotalária e sorgo (Castro, 1975).

Para medir a taxa de cruzamento natural, a maioria dos trabalhos citados em literatura, utiliza a metodologia sugerida por Cross \& Richmond (1959), através de um marcador genético que controla a presença e ausência de glândulas lisígenas nas sementes. Uma das características botânicas únicas do gênero Gossypium e de outros gêneros da tribo Gossypiae é a presença de glândulas lisígenas (pontuações escuras) em todos os tecidos da parte aérea (Fryxell, 1968, 1992).

Através de seleção a partir do algodão Hopi Moencopi (G. hirsutum var. punctatum), McMichael em 1940, obteve plantas com total ausência de glândulas nas folhas e frutos verdes (maçãs). Um gene recessivo, $g_{1}$, quando em homozigose recessiva $\left(\left.\left.g\right|_{1} g\right|_{1}\right)$, produz plantas sem glândulas de gossipol nas maçãs, hipocótilo, haste e pecíolos, mas com folhas e sementes contendo um número normal de glândulas. Dois genes, designados $\mathrm{gl}_{2} \mathrm{e} \mathrm{gl}_{3}$, controlam a presença de glândulas na semente. $\mathrm{Na}$ expressão dos genes $\mathrm{gl}_{2}$ e $\mathrm{gl}_{3}, 16$ combinações genotípicas são possíveis, sendo que somente em homozigose duplo-recessiva ( $\mathrm{gl}_{2} \mathrm{~g} \mathrm{l}_{2}-\mathrm{gl}_{3} \mathrm{~g} \mathrm{l}_{3}$, figura 2) a planta e as sementes apresentam ausência total de glândulas (McMichael, 1954, 1960). Uma característica que torna este marcador muito popular para determinar o cruzamento, é a observação da ocorrência de cruzamento diretamente através das sementes oriundas de plantas sem glândulas, não necessitando da avaliação de sua progênie (Frampton et al. 1960; Carter et al. 1966; Lukerfahr \& Fryxell, 1967). Quando isto ocorre diz-se que o caráter tem efeito de xênia, isto é, se manifesta sempre uma geração antes dos demais caracteres (Ramalho et al., 1997). As glândulas presentes no interior das sementes são visíveis a olho nu, o que facilita a avaliação de presença ou ausência das mesmas (Lusas \& Jividen, 1987). 
Apesar do gossipol contido nas glândulas, ter ação repelente as larvas de Heliothis spp. (Lukefahr et al. 1966; Hanny et al. 1979), não foi detectada diferença entre a taxa de visitação de abelhas entre genótipos com ou sem glândulas. O teor de gossipol detectado no grão de pólen foi extremamente baixo $(<0,003 \%$ do peso seco) (Loper, 1986).

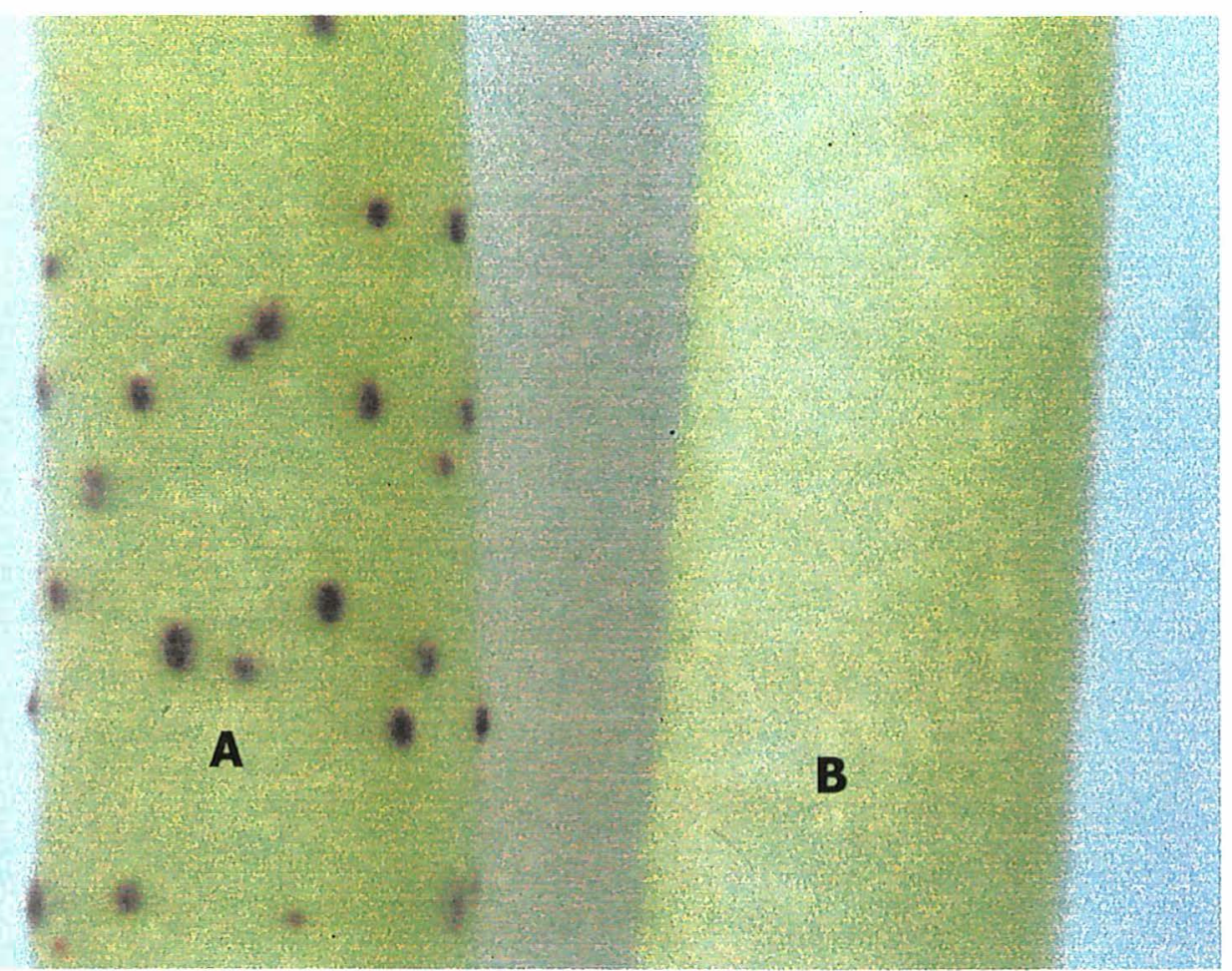

Figura 2 (A) Haste de planta com glândulas $\left(\mathrm{Gl}_{2}\right.$ - e ou $\mathrm{Gl}_{3}$-); demonstrando presença de glândulas; $(B)$ haste de planta sem glândulas $\left(\mathrm{gl}_{2} \mathrm{gl}_{2}-\right.$ $\mathrm{gl}_{3} g \mathrm{l}_{3}$ ). Lupa de Aumento de 10x.

A utilização de marcadores morfológicos para determinação da taxa de cruzamento, geralmente é efetuada da seguinte forma: (a) semeadura em fileiras alternadas com genótipos divergindo para um par de genes $e$ determinação da freqüência de cruzamento natural existente entre as fileiras de progênies; (b) utilização de plantas contrastantes para um caráter, alternadas em cada fileira; (c) indivíduos recessivos dentro de uma população portadora do 
respectivo alelo dominante; d) instalação de campos adjacentes divergindo para um caráter, com a finalidade de obter informações sobre contaminações entre campos instalados próximos (Free, 1993). A semeadura em fileiras alternadas tem sido o método mais freqüentemente utilizado.

\subsection{Estrutura genética do algodoeiro herbáceo}

Considerando o sistema reprodutivo, as espécies podem ser classificadas em autógamas (reprodução por autofecundação natural), alógamas (reprodução via cruzamento ao acaso entre plantas) e mistas (reprodução via autofecundação e cruzamento ao acaso). As espécies com sistema misto de reprodução são caracterizadas por apresentarem taxa de cruzamento natural (t) ou de autofecundação natural (s) intermediária em relação às espécies autógamas e alógamas.

Tabela 3 Classificação das espécies de plantas segundo o sistema reprodutivo.

\begin{tabular}{cc}
\hline Espécie & $\mathbf{t}(\%$ de cruzamento natural) \\
\hline Autógama & $0-5$ \\
Mista & $6-94$ \\
Alógama & $95-100$ \\
\hline
\end{tabular}

Nas espécies autógamas que apresentam endogamia máxima $(F=1)$, as plantas são totalmente homozigóticas para um único alelo de cada gene; nas espécies alógamas, sem endogamia, $(F=0)$, as plantas podem ser homozigotas nas freqüências $p^{2}$ ou $q^{2}$ ou heterozigotas com freqüência $2 p q$; nas espécies com sistema misto de reprodução, as plantas possuem diferentes taxas de 
endogamia e devem apresentar freqüências $p^{2}+p q F e q^{2}+p q F$ quando homozigóticas ou 2pq(1-F) quando heterozigótias (Tabela 4; Li, 1966).

Tabela 4 Genótipos e freqüências genotípicas de uma população em equilíbrio de Wright, com diferentes níveis de endogamia (F).

\begin{tabular}{cccc}
\hline & \multicolumn{3}{c}{ Freqüências Genotípicas } \\
\cline { 2 - 4 } Genótipos & $\mathbf{F}=\mathbf{0}$ & $\mathbf{0}<\mathbf{F}<\mathbf{1}$ & $\mathbf{F}=\mathbf{1}$ \\
\hline $\mathrm{AA}$ & $\mathrm{P}^{2}$ & $\mathrm{P}^{2}+\mathrm{pqF}$ & $\mathrm{P}$ \\
$\mathrm{Aa}$ & $2 \mathrm{pq}$ & $2 \mathrm{pq}(1-\mathrm{F})$ & 0 \\
aa & $\mathrm{q}^{2}$ & $\mathrm{q}^{2}+\mathrm{pqF}$ & $\mathrm{q}$ \\
\hline
\end{tabular}

O coeficiente de endogamia ( $F$ ) quantifica a homozigose existente na população e está em função da taxa de autofecundação natural (s) ou da taxa de cruzamento natural $(t)$ :

$$
F=\frac{s}{2-s} \text { ou } F=\frac{1-t}{1+t}
$$

dessa maneira, à medida em que a taxa de cruzamento natural $(t)$ da população aumenta, a endogamia populacional tende a diminuir.

O coeficiente de endogamia, no entanto, é um coeficiente médio da população. Nas populações com sistema misto de reprodução, as plantas apresentam diferentes coeficientes de endogamia e, consequentemente, diferente taxas de autofecundação natural, isto é, as populações são formadas de indivíduos autofecundados na proporção se cruzados na proporção $t=1-s$ (Wright \& Cockerham, 1985).

Nas espécies intermediárias ou mistas, as populações quando fora do equilíbrio de Wright, não retornam ao equilíbrio após uma geração de 
cruzamento ao acaso, como nas espécies alógamas. O número de gerações de polinização aberta $\left(\mathrm{N}_{\text {gca }}\right)$ necessário para que a população atinja determinada proporção (x) até o equilíbrio é: $N g c a=\frac{\log (1-x) / s}{\log (s / 2)}$ (Pereira et al., 1986).

Crisóstomo (1989) através de simulação de dados de seleção genealógica de uma população hipotética, com variabilidade, considerou na geração inicial $F=0,56$ que passou para $F=0,89$ na população melhorada, após duas gerações de autofecundação. As plantas dessa população, após multiplicação da sementes genéticas, abrem o sistema de recombinação, retornando a uma taxa média de cruzamento de $28,6 \%$. Se estas condições forem mantidas, e considerando-se um gene com dois alelos, a população atingirá $99 \%$ do equilíbrio de Wright, após cerca de cinco gerações de reprodução natural (Pereira et al, 1983). Nestas condições, o coeficiente de endogamia será de $\mathrm{F}=0,56$ e diferente, portanto, das estimativas originais $(0,89)$. Este fato leva a um novo arranjo das freqüências genotípicas, podendo acarretar alterações na média populacional e desuniformidade nos caracteres econômicos, sobretudo de fibra, o que é importante de ser mantido no algodoeiro. Certamente, esse é um dos fatores da degeneração de variedades de algodoeiro e de outras espécies de reprodução mista, fato que justifica a produção contínua de sementes genéticas (Crisóstomo, 1989).

A falta de condições genéticas estáveis, faz com que os seus métodos de melhoramento não sejam tão bem definidos para o algodoeiro. Neste sentido, muitos programas de melhoramento, apesar de utilizarem os mesmos processos de hibridação, apresentam diferenças quanto aos detalhes de condução (Poehlman, 1959).

Nas espécies de sistema misto de reprodução, o ponto de equilíbrio é atingido quando o valor de " $F$ " estiver estabilizado. Nesta situação, a proporção dos heterozigotos, num dado loco com dois alelos, fica igual a 2pq (1-F) e a dos respectivos homozigotos igual a $p^{2}+p q F$ e $q^{2}+p q F$ (Crisóstomo, 1989). 
A condição de cruzamento parcial do algodoeiro apresenta, também, aspectos benéficos como a recombinação gênica, que ocorre naturalmente, e que amplia a variabilidade. Tal fato possibilita o progresso genético pela seleção dentro de variedades superiores, em cultivo há algum tempo (Meredith, 1979; Gridi-Papp et al. 1984). Essa taxa parcial de cruzamento natural possibilita ainda, o emprego de esquemas que incrementam a recombinação, a quebra de ligações indesejáveis e o emprego de métodos de seleção recorrente, notadamente nas áreas de maior taxa de cruzamento (Crisóstomo, 1989).

O algodoeiro herbáceo (G. hirsutum) tem sido classificado como planta do grupo intermediário quanto ao seu modo de reprodução. A existência de cruzamento natural no algodão foi identificada a várias décadas, sua magnitude, entretanto, varia consideravelmente de acordo com as condições locais (Tabela 2). Determinar a taxa de cruzamento natural no algodoeiro é uma prática essencial, pois possibilita a verificação do sistema reprodutivo predominante, da estrutura genética, do número de gerações de polinização aberta necessário para que seja atingido o equilíbrio, além da estimação do progresso genético esperado com a seleção. A necessidade de determinar $e$ delimitar os niveis de autofecundação e cruzamento é ainda, fator primordial para o entendimento dos processos evolutivos e melhor aplicação das estratégias de melhoramento, já que os métodos de melhoramento das espécies autógamas, alógamas e mistas diferem entre si (Richards, 1997).

Dessa maneira, informações a respeito da dispersão de pólen são vitais para o entendimento da estrutura genética de populações em termos de nivel de heterozigose, manutenção e quebra de grupos de ligação, estabelecimento de novos mutantes e melhoramento genético de populações pequenas (Richards, 1997). 


\subsection{Manutenção da pureza varietal}

Existem algumas controvérsias sobre quanto o cruzamento natural contribui para a deterioração da pureza varietal desta espécie. No passado, as misturas encontradas foram geralmente atribuídas ao processamento das sementes nas unidades de beneficiamento. Entretanto, atualmente a deterioração genética das variedades dificilmente é devida a este fator, já que através da modernização do sistema e controle de qualidade, as misturas na fase de beneficiamento são mínimas.

Assim, a grande oscilação de cruzamento às quais as variedades de algodão estão sujeitas, é uma das razões da rápida deterioração da pureza varietal desta espécie quando comparada com espécies autofecundadas como a soja. Isto resulta na maior necessidade de utilização de sementes com atestado de origem pelos agricultores. Existem evidências de que variedades mais uniformes não percam sua identidade genética tão rapidamente quanto outras mais desuniformes.

No Tennessee, EUA, quatro variedades uniformes foram cultivadas por cinco anos sucessivos, evitando cruzamentos e mistura no beneficiamento. Durante este periodo não foram encontradas diferenças significativas na produção, peso de capulhos, porcentagem de línter, tamanho da fibra, uniformidade de fibras, resistência ou finura das fibras. Estes resultados indicam que trocas genéticas podem não ocorrer se uma variedade uniforme for conduzida sob rigoroso controle de qualidade. Duas das variedades utilizadas foram desenvolvidas por seleção dentro de linhas autofecundadas e eram extremamente uniformes. Em área onde algumas variedades são produzidas e ocorrem altas taxas de cruzamento, as sementes produzidas em uma estação podem apresentar misturas muito maiores do que a que ocorre nas unidades de beneficiamento (Simpson \& Duncan, 1953).

Obviamente, a pureza varietal pode ser garantida pelo produtor de sementes através do conhecimento da taxa de cruzamento de sua área e 
determinação das medidas necessárias para o isolamento da cultura. Neste contexto, a utilização de variedades transgênicas só será possível quando técnicas de isolamento forem comprovadamente seguras para conter a movimentação de pólen. Através de estudo desenvolvido no Estado do Mississippi, EUA, a fim de se determinar a distância de dispersão de pólen de algodão transgênico, constatou-se uma taxa de cruzamento de $5 \%$ a $<1 \%$ até 7 metros de distância do campo de algodão transgênico. As sementes foram analisadas para expressão do um marcador dominante - neomicina fosfotranferase (NPTIII) sendo que o campo possuia as dimensões determinadas pelo USDA, para um teste de variedade (Umbeck et al., 1991). $\mathrm{Na}$ Austrália, para isolamento de um campo de plantas transgênicas, contendo o gene de Bacillus thurigiensis (bt) e um gene da neomicina fosfotransferase (NPTII), foi determinado uma distância de 20 metros de bordadura de algodão não-transgênico como barreira segura ( Leewellyn \& Fitt, 1996). Em trabalho semelhante desenvolvido em Beijing, China, foi avaliada a dispersão de pólen transgênico através de um gene marcador (tfda) que confere resistência ao herbicida 2,4D. A partir da avaliação de sementes coletadas em campos adjacentes foi estimada uma freqüência de $11,2 \%$ a 1 metro de distância, decrescendo para 0,$61 ; 0,16 ; 0,09$ e $0,03 \%$ a $5,10,20$ e 50 metros, respectivamente (Zhang-Changqing, et al., 1997).

Antes que variedades transgênicas sejam liberadas, é necessário a condução de vários testes exigidos pelas leis de biossegurança, a fim de determinar que as plantas modificadas não tem efeito deletério ao ambiente. No caso do algodoeiro, a determinação da disseminação de pólen a partir de plantas transgênicas, é fator primordial para aprovação de variedades geneticamente modificadas (Leewellyn \& Fitt, 1996). 


\section{MATERIAL E MÉTODOS}

\subsection{Determinação da taxa de cruzamento natural}

A taxa de cruzamento natural ( $t$ ) foi determinada através de metodologia sugerida por Cross \& Richmond (1959). Entretanto houve diferença entre as técnicas utilizadas nos anos agrícolas 1997/98 e 1998/99.

No ano agrícola $1997 / 98$ foi realizado um ensaio preliminar, instalado em 18/12/97, no campo experimental da Fundação de Apoio à Pesquisa Agropecuária de Mato Grosso (FUNDAÇÃO MT), localizado na Fazenda Ponte de Pedra, município de Rondonópolis-MT. As sementes de plantas sem glândulas foram semeadas alternadamente com fileiras de plantas com glândulas em 16 parcelas de $32,4 \mathrm{~m}^{2}$, ou seja, quatro fileiras de $10 \mathrm{~m}$ de comprimento espaçadas $0,9 \mathrm{~m}$, entre si e intercaladas entre as bordaduras dos ensaios de linhagens e variedades de algodão (Figura 3 ). As bordaduras foram compostas por quatro fileiras da variedade CNPA ITA 90.

No período de colheita, as duas fileiras das 16 parcelas foram colhidas separadamente. As amostras foram coletadas em duas épocas, 22/05/98 e 05/06/98. Após o descaroçamento dos capulhos, foram retiradas oito amostras de 50 sementes de cada fileira, as quais foram colocadas para germinar em papel toalha, sendo avaliadas após quatro dias (Novembre, 1990). Em cada amostra foram contadas as plântulas com glândulas e sem glândulas, sendo o percentual médio de plantas com glândulas observado, considerado como sendo a taxa de cruzamento natural do algodoeiro nesta área. 

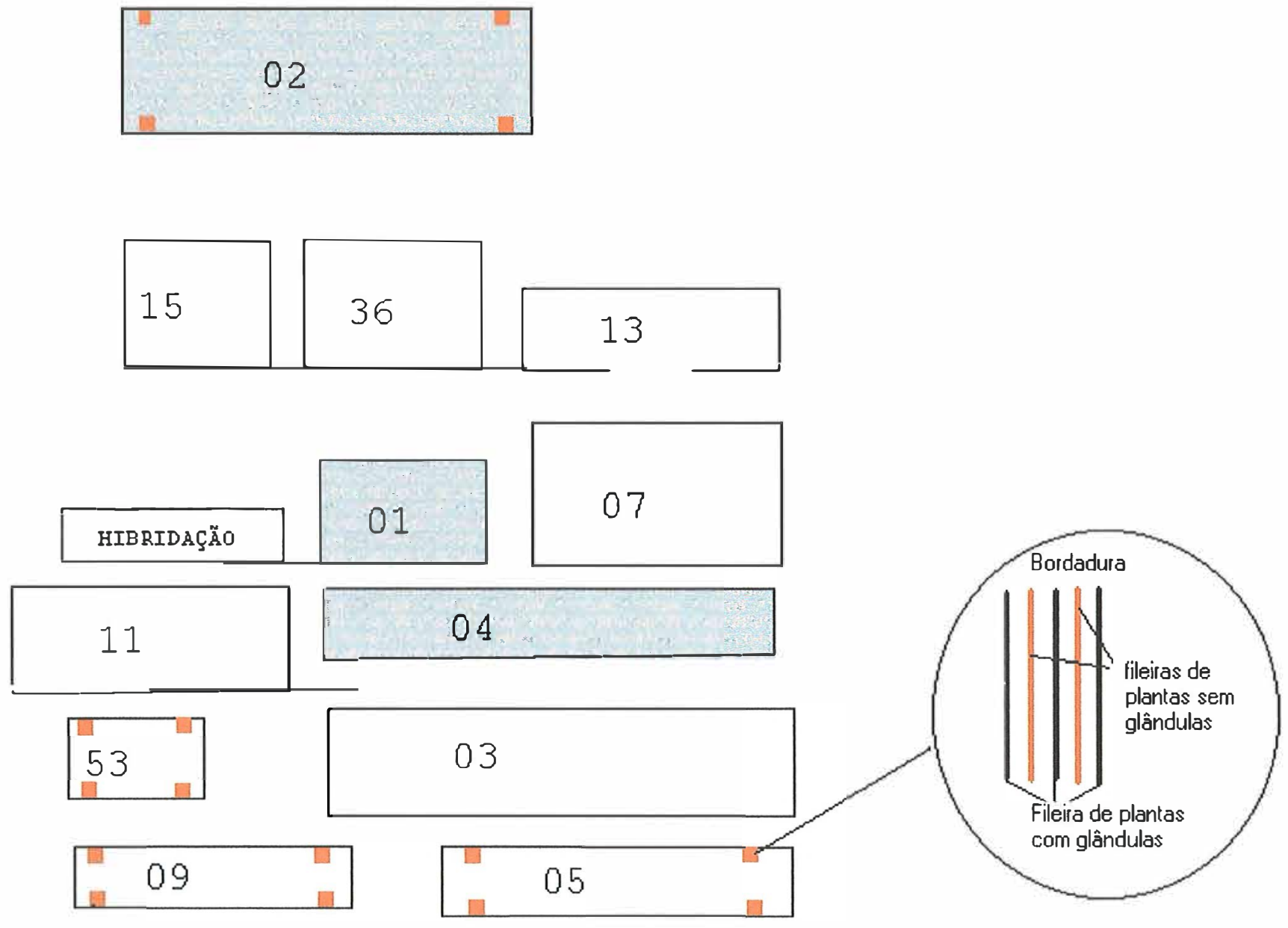

Figura 3. Disposição das 16 parcelas de plantas sem glândulas (em vermelho) no campo de plantas com glândulas, junto aos ensaios identificados pelos números.

No ano agrícola de 1998/99 foram instalados oito ensaios para determinação da taxa de cruzamento em seis diferentes localidades do estado de Mato Grosso (Figura 04): (a) Serra da Petrovina (Fazenda Girassol), duas áreas; (b) município de Pedra Preta, dois locais; (c) município de Rondonópolis 
(Fazenda SM2); (d) município de Campo Verde (Fazenda Marabá); (e) município de Primavera do Leste (Fazenda Juriti); (f) município de Campo Novo dos Parecis (Fazenda Itamarati Norte). Nesta etapa foi utilizada a metodologia de plantas sem glândulas isoladas em um bloco de outra cultivar portadora de glândulas (Figura 5). As sementes das plantas sem glândulas foram semeadas 10 dias após as plantas com glândulas. A instalação das covas foi efetuada em 30 a 50 pontos distanciados aproximadamente 15 metros entre si, dispersos na área experimental entre os ensaios de caracterização varietal, compostos dos seguintes genótipos: CNPA ITA 90, CNPA ITA 96, BRS ANTARES, BRS FACUAL, BRS ITA 94-151, BRS ITA 94-743, BRS ITA 94-773, BRS ITA 94-122. Somente nos locais Pedra Preta I e II, os ensaios foram instalados em lavoura comercial sem identificação da variedade utilizada, já que as sementes foram retiradas de safras anteriores pelo próprio agricultor. A descrição do período de florescimento para cada genótipo, está disponível em apêndice.

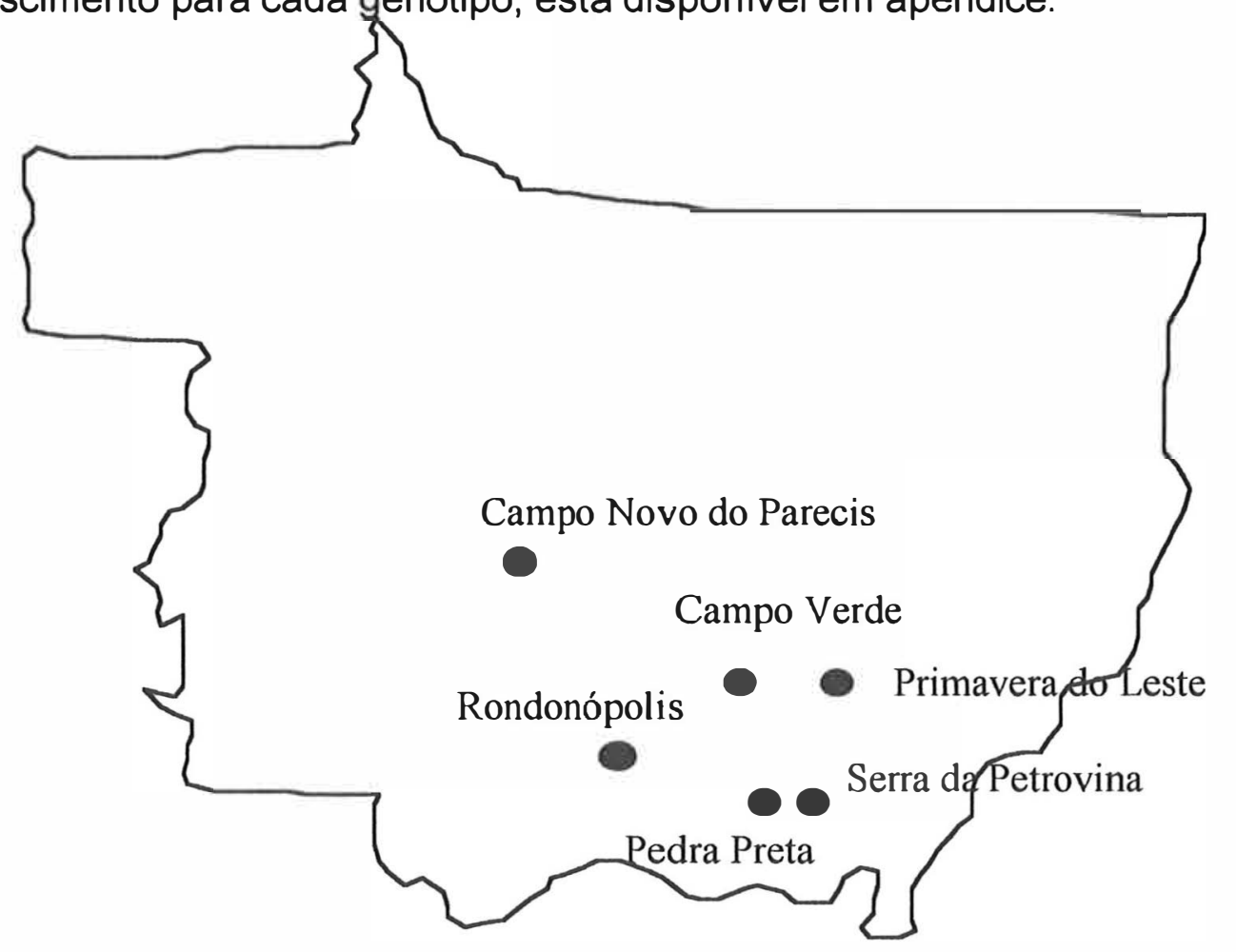

Figura 4 Mapa do Estado de Mato Grosso demonstrando os locais avaliados. 
No período que antecedeu a colheita dos campos foram coletados todos os capulhos produzidos pelas plantas sem glândulas.

Em caso de perda das plantas sem glândulas pela ocorrência de pragas e/ou doenças, uma medida paliativa foi tomada, através da aferição indireta da dispersão de pólen pelo emprego do azul de metileno $\left(\mathrm{C}_{16} \mathrm{H}_{18} \mathrm{CIN}_{3} \mathrm{~S} .3 \mathrm{H}_{2} \mathrm{O}\right)$. $\mathrm{O}$ azul de metileno foi aplicado em todas as flores da primeira fileira do campo, numa extensão de 100 metros. A dispersão intrapopulacional foi determinada nas demais flores remanescentes no campo. À tarde, com o auxílio de um nebulizador, borrifava-se água em todas as flores do campo, contando aquelas manchadas pela substância.

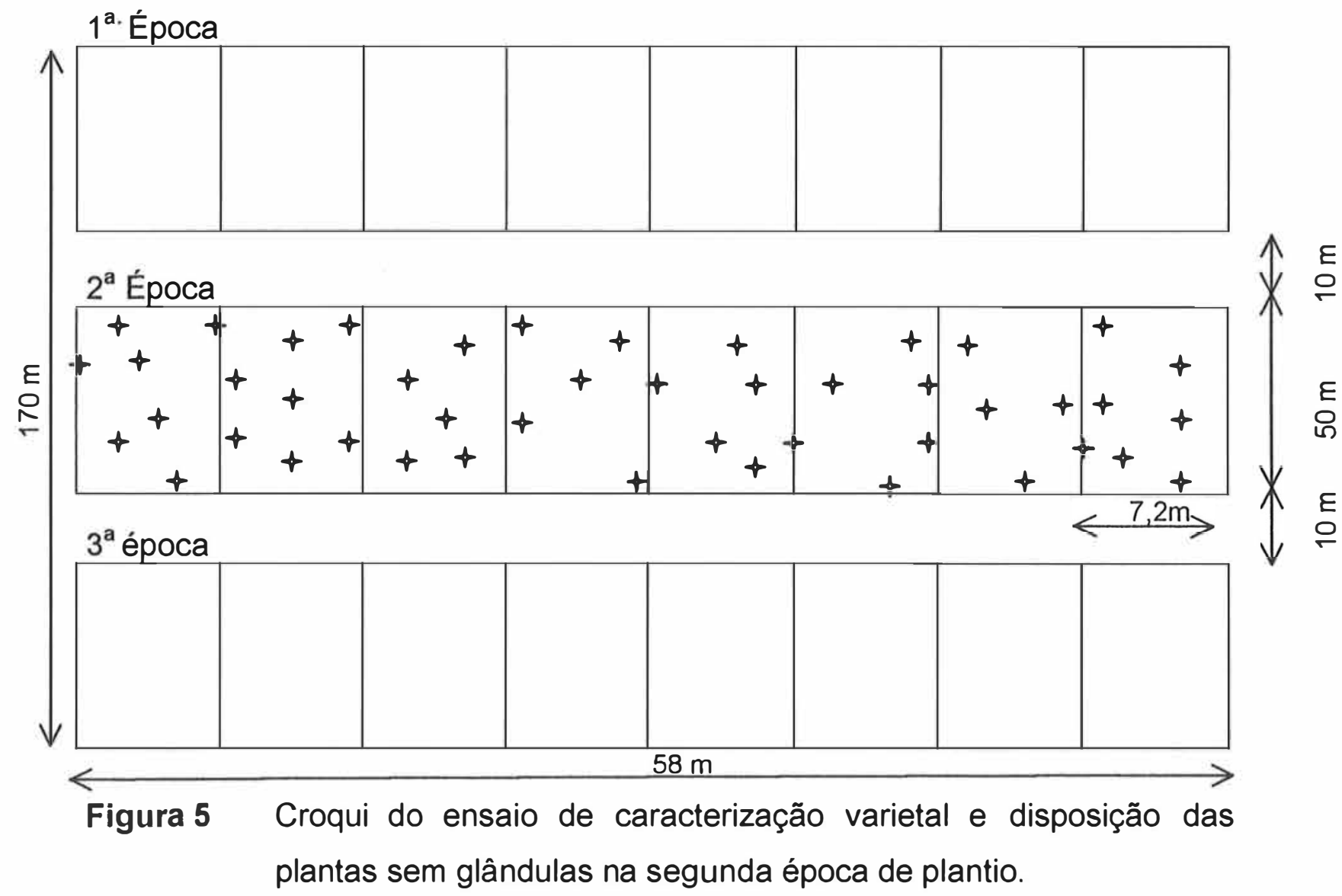




\subsection{Dispersão de pólen}

Para determinar a distância e direção da dispersão de pólen através de insetos, foi instalada uma área de $20 \times 20 \mathrm{~m}$ (21 fileiras de 20 metros) de algodão sem glândulas, isolado por uma barreira de crotalária (Crotalaria junceae) (3,6 m), na Estação Experimental da FUNDAÇÃO MT, Fazenda SM2, no município de Rondonópolis - MT (Figura 6). Este ensaio foi disposto a uma distância de 500 metros de outros campos de algodão, tendo como culturas vizinhas a soja e pastagem. Na região central do campo foram plantadas duas plantas de algodão com glândulas $\left(\mathrm{GL}_{2} \mathrm{GL}_{2} \mathrm{GL}_{3} \mathrm{GL}_{3}\right)$. Após a germinação (20 dias) foi efetuado o desbaste a fim de eliminar todas as plantas com glândulas, exceto as duas da região central. No período de colheita foram coletadas amostras de cinco capulhos, retirados da parte mediana de cada planta do campo. A partir dos dados coletados foi avaliado o percentual de cruzamento e o percentual de plantas visitadas.

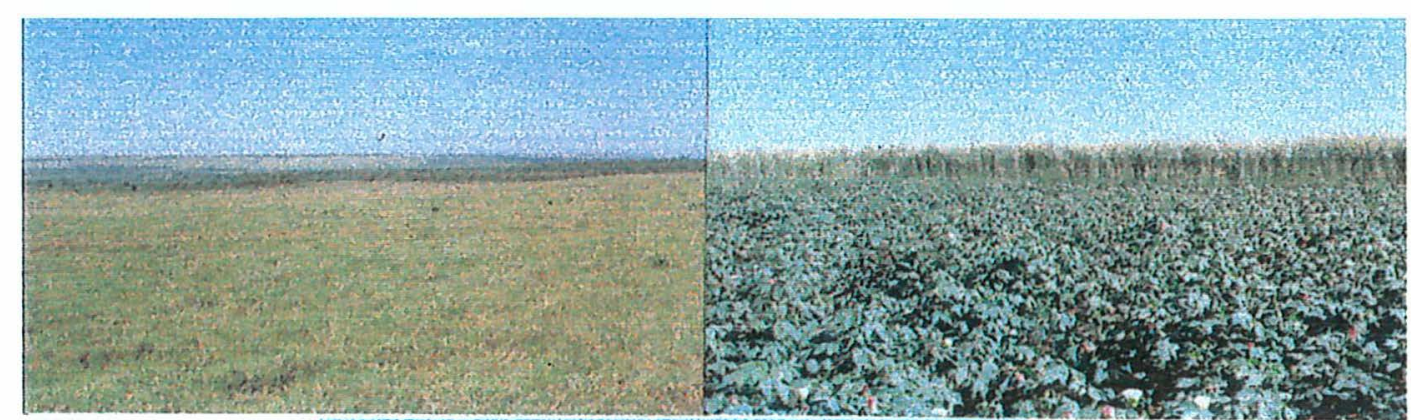

A

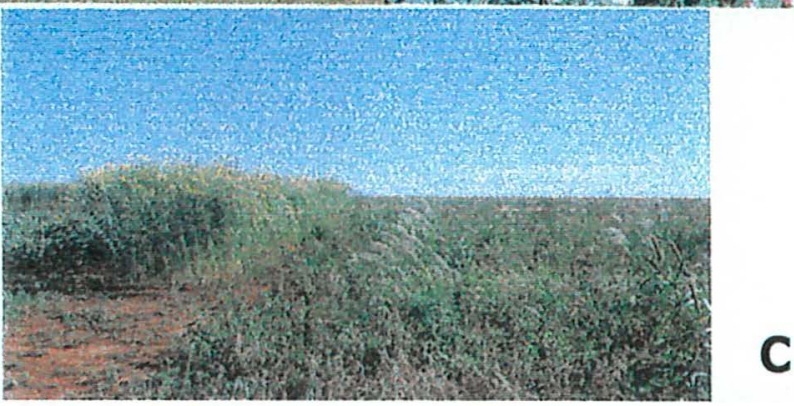

Figura 6 Ensaio de avaliação de distância de dispersão de pólen. (A) pastagem localizada ao Sul da área avaliada; (B) Vista lateral; (C) detalhe mostrando a característica das demais áreas vizinhas (Norte, Leste e Oeste). 
Para avaliação da distância de dispersão do pólen, a área foi subdividida em raios de $3,0 \mathrm{~m} ; 4,5 \mathrm{~m} ; 6,0 \mathrm{~m} ; 7,5 \mathrm{~m} ; 9,0 \mathrm{~m}$ e $10 \mathrm{~m}$ de diâmetro do centro de dispersão de pólen (Figura 7). Para avaliação da direção de dispersão a mesma área foi dividida para as direções Norte, Sul, Leste e Oeste (Figura 8).

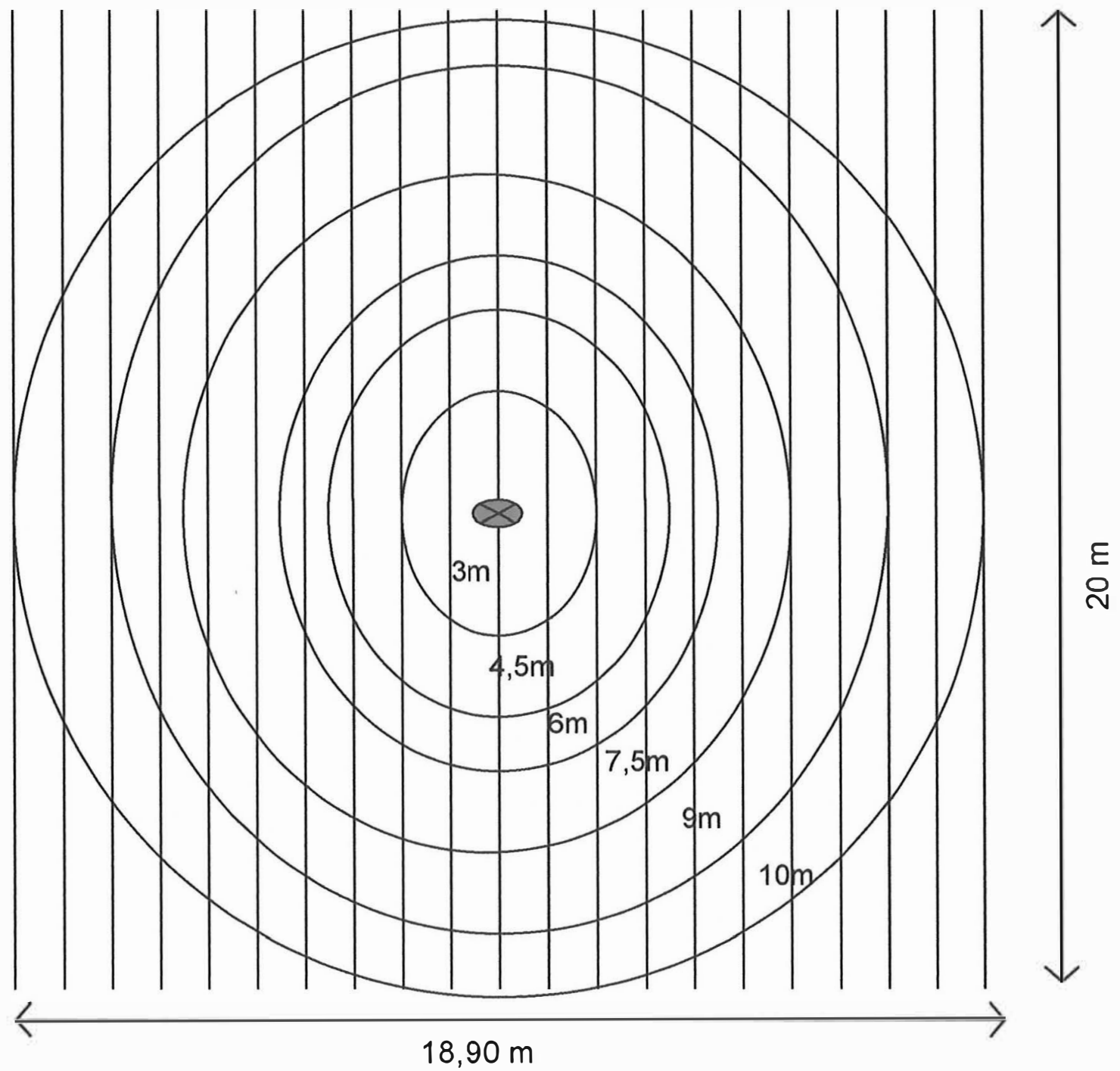

Figura 7 Representação esquemática das distâncias avaliadas. 


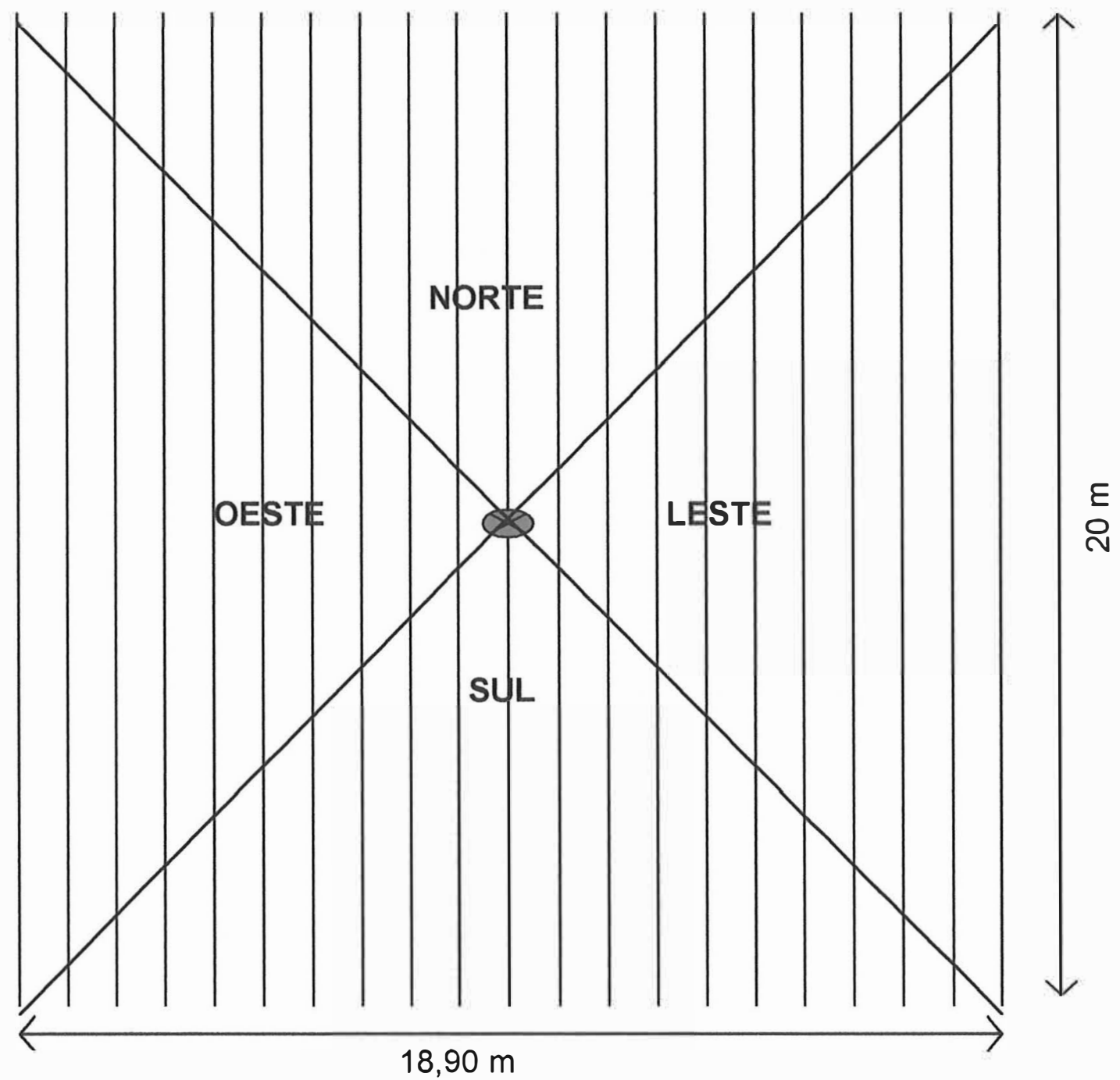

Figura 8 Representação esquemática das direções de dispersão de pólen avaliadas.

\subsection{Eficiência do sistema de isolamento}

O experimento foi instalado na Estação Experimental da FUNDAÇÃO MT, Fazenda SM2, no município de Rondonópolis-MT. As plantas sem glândulas foram cultivadas em um campo de $10 \times 14,4 \mathrm{~m}$ (16 fileiras de 10 metros, espaçadas a $0,9 \mathrm{~m}$ ) juntamente com os demais campos de pequeno aumento das linhagens testadas. O campo foi desbastado 20 dias após a emergência, a fim de eliminar possíveis misturas de sementes com glândulas. 
$\mathrm{O}$ isolamento dos campos foi efetuado através de barreiras formada por 16 fileiras (0,9 m de espaçamento) de crotalária (Figura 9). Por ocasião da colheita foram coletados cinco capulhos da parte mediana de cada planta do campo de plantas sem glândulas. A partir dos dados coletados foram avaliados 0 percentual de cruzamento e o percentual de plantas visitadas.

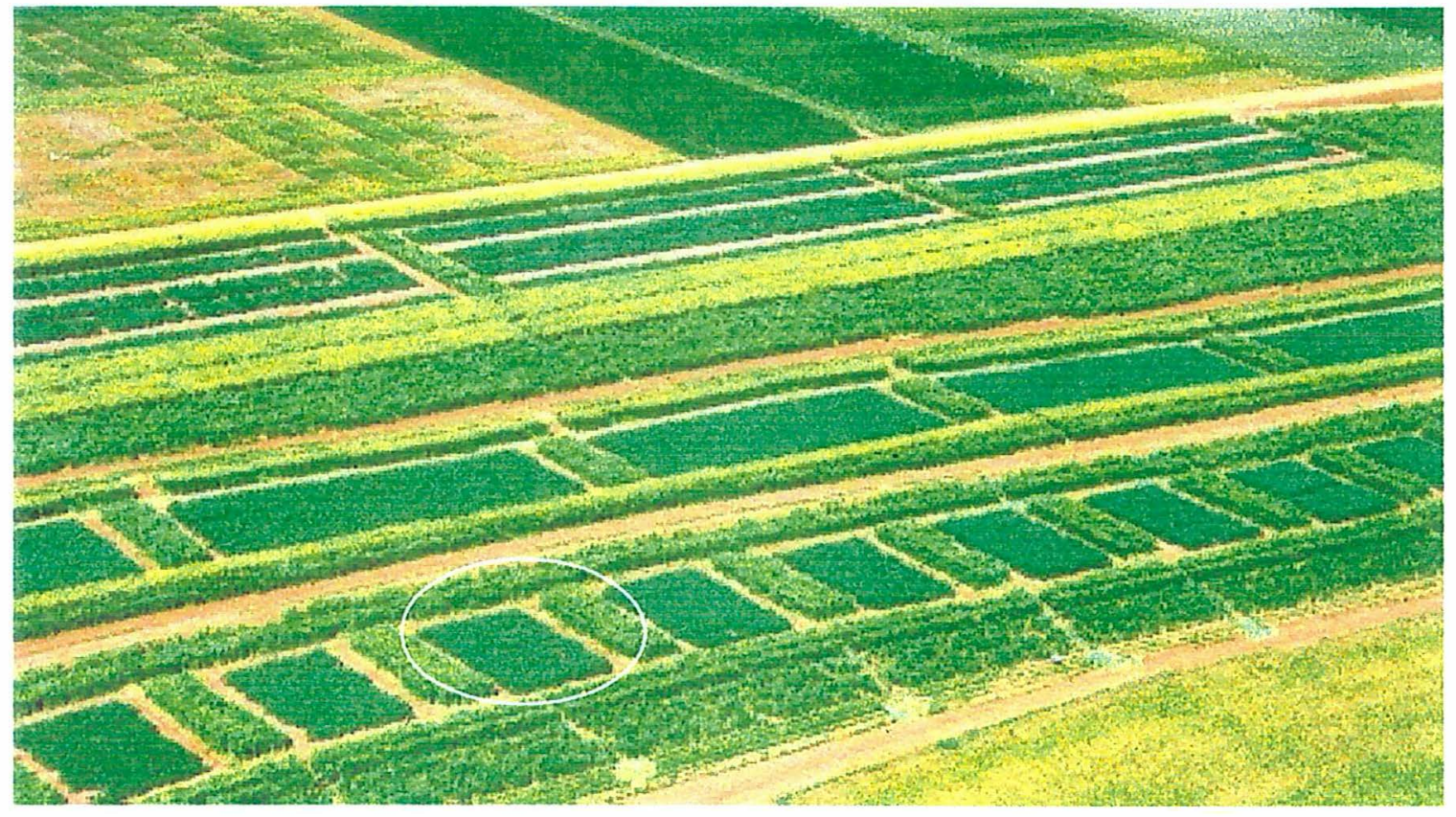

Figura 9 Vista aérea dos campos de pequeno aumento, entre estes 0 de plantas sem glândulas (dentro do círculo). Cores amarelas e verde claras representam barreiras de isolamento cultivadas com crotalária.

\subsection{Avaliação da população de plantas sem glândulas}

A população de plantas sem glândulas foi cedida pela Empresa Brasileira de Pesquisa Agropecuária - Centro Nacional de Algodão (EMBRAPAALGODÃO), sendo recomendado a verificação da pureza genética do material a partir de semedura em área isolada. Para tanto, em 30/10/98 foi realizado a semeadura de uma amostra de sementes numa área de $10 \times 10 \mathrm{~m}$ (10 fileiras 
de 10 metros) no campo experimental da Escola Superior de Agricultura "Luiz de Queiroz" (ESALQ), no município de Piracicaba-SP. Este campo foi instalado em local isolado no tempo e espaço de outras áreas em que a cultura foi instalada (aproximadamente 500 metros). As amostras foram retiradas no período de abertura dos capulhos, sendo duas amostras de cinco capulhos de cada fileira, perfazendo 100 capulhos amostrados.

\subsection{Avaliação das amostras coletadas a campo}

Para determinação da ocorrência de cruzamento, os capulhos coletados foram descaroçados em máquinas de rolo onde as sementes puderam ser separadas. Após este processamento, as sementes foram secionadas, e foi contado o número de sementes com glândulas oriundas de plantas sem glândulas (Figura 10). As glândulas, quando presentes no embrião, são facilmente identificadas e indicam a ocorrência de cruzamento entre plantas (McMichael, 1954, 1960; Lee, 1980).

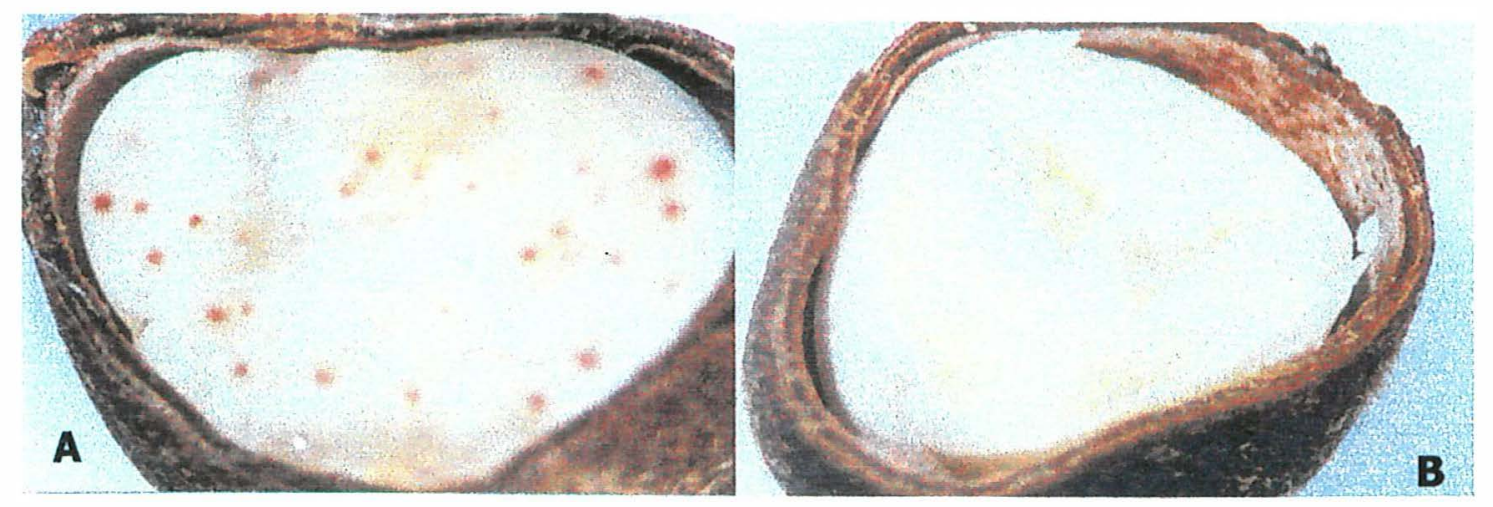

Figura 10 Sementes secionadas, mostrando o tegumento, onde (A) semente portadora de alelo dominante para presença de glândulas e (B) sementes portadoras de alelos recessivos para ausência de glândulas. 


\subsection{Análise estatística}

Inicialmente foram realizadas as análises de estatística descritiva para cada local e experimento. Nesta análise, foram mensurados os seguintes parâmetros:

N: Número de plantas sem glândulas avaliadas;

$\mathbf{X}_{\text {min }}$ : Menor valor referente ao percentual de sementes com glândulas encontradas nas plantas sem glândulas avaliadas (percentual mínimo de cruzamento);

$\mathbf{X}_{\max }$ : Maior valor referente ao percentual de cruzamento;

Amplitude: Diferença entre 0 maior e 0 menor percentual de cruzamento: $X_{\max }-X_{\min }$;

Média: Média aritmética do percentual de cruzamento: $\bar{x}=\sum_{i=1}^{n} x_{i} / n$;

Variância: Estimativa da variância do percentual de cruzamento:

$$
s^{2}=\sum_{i=1}^{n}\left(x_{i}-\bar{x}\right)^{2} /(n-1)
$$

Desvio padrão: Desvio padrão do percentual de cruzamento: $s=\sqrt{s}^{2}$.

Posteriormente, foram feitos testes de independência da taxa de cruzamento comas variáveis datas de colheita, locais e direções de disseminação de pólen, através da aplicação do Teste qui-quadrado $\left(\boldsymbol{x}^{2}\right)$, segundo Steel \& Torrie (1980):

$$
x^{2}=\sum \frac{(f o-f e)^{2}}{f e}
$$


Onde:

fo: freqüência observada;

fe: freqüência esperada quando a hipótese é verdadeira, isto é, para os valores teóricos.

Os dados obtidos foram organizados em tabelas da seguinte forma:

Tabela 5 Resumo do Teste $\boldsymbol{x}^{2}$ :

\begin{tabular}{|c|c|c|c|c|}
\hline Tratamentos & Frequência & CG & SG & Total \\
\hline \multirow[t]{3}{*}{ Trat 1} & Observada & $\operatorname{cg} 1$ & $\operatorname{sg} 1$ & $\operatorname{cg} 1+\operatorname{sg} 1$ \\
\hline & Esperada & $(\operatorname{cg} 1+\operatorname{sg} 1) * \sum \mathrm{cg} / 2(\mathrm{cg}+\mathrm{sg})$ & $(\operatorname{cgl} 1+\mathrm{sg}) * * \Sigma \mathrm{sg} / \Sigma(\mathrm{cg}+\mathrm{sg})$ & \\
\hline & $x^{2}$ & $(\mathrm{fo}-\mathrm{fe})^{2} / \mathrm{fe}$ & $(\mathrm{fo}-\mathrm{fe})^{2} / \mathrm{fe}$ & \\
\hline \multirow[t]{3}{*}{ Trat 2} & Observada & $\operatorname{cg} 2$ & $\mathrm{sg} 2$ & $\operatorname{cg} 2+\operatorname{sg} 2$ \\
\hline & Esperada & $(\mathrm{Cg} 2+\mathrm{sg} 2)^{*} \Sigma \mathrm{cg} / 2(\mathrm{cg}+\mathrm{sg})$ & $(\mathrm{Cg} 2+\mathrm{sg} 2) * \Sigma \mathrm{sg} / 2(\mathrm{cg}+\mathrm{sg})$ & \\
\hline & $x^{2}$ & $(\text { fo-fe })^{2} / \mathrm{fe}$ & $(\mathrm{fo}-\mathrm{fe})^{2} / \mathrm{fe}$ & \\
\hline$\vdots$ & $\vdots$ & $\vdots$ & $\vdots$ & $\vdots$ \\
\hline \multirow[t]{3}{*}{ Trat $n$} & Observada & $\operatorname{cgn}$ & sgn & $\mathrm{Cgn}+\mathrm{sgn}$ \\
\hline & Esperada & $(C g n+s g n)^{*} \Sigma c g / \Sigma(\operatorname{cg}+s g)$ & $(\operatorname{cgn}+s g n)^{*} \Sigma s g / \Sigma(g \mathrm{~g}+\mathrm{sg})$ & \\
\hline & $x^{2}$ & $(f o-f e)^{2} / f e$ & (fo-fe $)^{2} / \mathrm{fe}$ & \\
\hline \multirow[t]{2}{*}{ Total } & Observado & $\Sigma c g$ & $\Sigma$ sg & $\sum(c g+s g)$ \\
\hline & $x^{2}$ & & & $\Sigma(\mathrm{fo}-\mathrm{fe})^{2} / \mathrm{fe}$ \\
\hline
\end{tabular}

Obs:

CG e SG: número de sementes com e sem glândulas, respectivamente.

Trat. 1, Trat. 2, ..., Trat. n: Tratamentos testados para as variáveis data de colheita, locais e direções de disseminação de pólen.

Onde: 
Data de colheita:

Tratamento 1: Primeira colheita efetuada em 22/05/98

Tratamento 2: Segunda colheita efetuada em 05/06/98

Locais:

Tratamento 1: Campo Verde

Tratamento 2: Serra da Petrovina I

Tratamento 3: Serra da Petrovina II

Tratamento 4: Primavera do Leste

Tratamento 5: Pedra Preta I

Tratamento 6: Pedra Preta II

Direções de dispersão de pólen:

Tratamento 1: Norte

Tratamento 2: Oeste

Tratamento 3: Leste

Tratamento 4: Sul

\subsubsection{Avaliação da distância de dispersão do pólen}

Para avaliação do ensaio de dispersão de pólen (item 3.2), as médias dos dados coletados para percentual de plantas visitadas e percentual de cruzamento, em cada intervalo de distância do centro de dispersão de pólen, foram submetidas à análise de regressão sendo as equações selecionadas através dos maiores coeficientes de determinação $\left(r^{2}\right)$, indicativos das maiores 
correlações entre as médias observadas e as esperadas pela equação de regressão.

Foi testada ainda a correlação entre o percentual de sementes oriundas de cruzamento (\% de cruzamento) e o percentual de plantas visitadas, através do coeficiente de correlação do momento do produto (Pearson), dado pela fórmula:

$$
r=\frac{n\left(\sum X Y\right)-\left(\sum X\right)\left(\sum Y\right)}{\sqrt{\left[n \sum X^{2}-\left(\sum X\right)^{2}\left[n \sum Y^{2}-\left(\sum Y\right)^{2}\right]\right.}}
$$

Onde,

r: correlação ou um índice sem dimensão situado entre -1,0 e 1,0 inclusive, que reflete a extensão de uma relação linear entre dois conjuntos de dados.

n: número de observações

$X:$ Variável - percentual de cruzamento

Y: Variável - percentual de plantas visitadas

\subsection{Identificação dos agentes polinizadores}

Como os insetos são os principais agentes polinizadores, foi efetuada a coleta e identificação dos insetos que possivelmente estivessem polinizando o algodoeiro nos locais avaliados. Os insetos coletados foram identificados e classificados pelo Departamento de Entomologia, Fitopatologia e Zoologia Agrícola da ESALQ/USP, Piracicaba-SP. 


\section{RESULTADOS E DISCUSSÃO}

\subsection{Taxa de cruzamento natural}

Através da análise descritiva dos dados referentes ao ensaio realizado em Rondonópolis, no ano agrícola 1997/98, foi verificado uma grande amplitude de variação dos dados coletados ( 0 a $71 \%$ ), e valor médio indicando uma taxa de cruzamento natural de $16,46 \%$. Este valor é considerado alto no tocante ao isolamento de parcelas. Estimou-se ainda um desvio padrão $(\sigma)$ de $5,01 \%$ e variância $\left(\sigma^{2}\right)$ de $25,15 \%$ entre os dados obtidos.

A Figura 11 mostra que a taxa de cruzamento da primeira colheita $(22 / 05 / 98,7,40 \%)$ foi muito menor do que a da segunda colheita (05/06/98, $20,68 \%$ ) As sementes coletadas na primeira colheita provém de frutos amadurecidos em período anterior ao da segunda colheita, ou seja, os primeiros foram fecundados em período também anterior aos últimos. $O$ aumento do cruzamento é devido à diminuição do número de flores, que torna mais intensa a atividade das abelhas (Free, 1993). O número de plantas visitadas por cada inseto polinizador tende a aumentar com o decréscimo do número de flores presentes; consequentemente o número de plantas visitadas é menor no período de máxima floração e maior nos períodos de início e de termino da floração (Stephens \& Finker, 1953). 


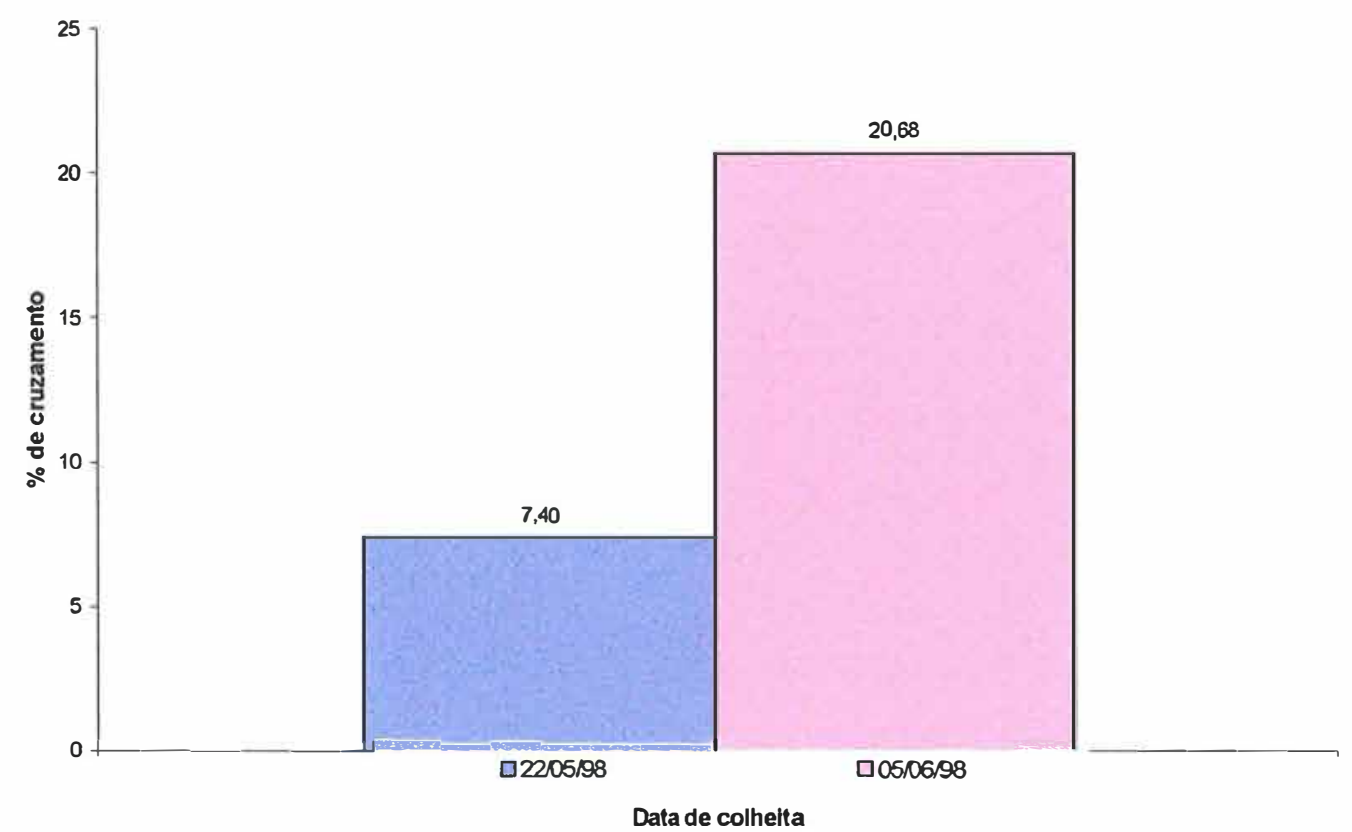

Figura 11 Taxa de cruzamento natural em duas diferentes épocas de colheita do algodoeiro em Rondonópolis-MT.

A partir dos dados obtidos (Figura 11), pode ser sugerido, que para a diminuição do percentual de contaminação entre diferentes genótipos, seja considerada somente a colheita da primeira época de colheita para multiplicação de sementes. No caso analisado, a média de mistura varietal detectada de $16,46 \%$ poderia ser diminuída para $7,40 \%$, ou seja, uma diminuição de $55,04 \%$.

A metodologia empregada para medir a taxa de cruzamento neste ensaio, apesar de ser a mais utilizada pelos pesquisadores (Free, 1993), apresenta uma limitação, já que o cultivo de fileiras adjacentes pode subestimar a taxa de cruzamento natural. Deste modo a metodologia mais apropriada é a de plantas com gene marcador (alelo recessivo) isoladas em campos de outra 
variedade com o outro fenótipo (alelo dominante). Esta metodologia foi adotada nos ensaios conduzidos no ano agrícola 98/99.

Os resultados da análise descritiva do ano 98/99 para os locais Serra da Petrovina I, Serra da Petrovina II, Pedra Preta I, Pedra Preta II, Campo Verde e Primavera do Leste estão dispostos na Tabela 6. Os dados referentes aos locais: Campo Novo dos Parecis e Rondonópolis não foram obtidos devido à ocorrência de pestes: em Campo Novo dos Parecis houve incidência de percevejo castanho (Saptoris castanea) na área experimental e, em Rondonópolis as plantas foram mortas por virose (mosaico das nervuras $f$. Ribeirão Bonito). Nesta última localidade o percentual de plantas visitadas por insetos polinizadores foi mensurada através da metodologia do azul de metileno, encontrando um valor de aproximadamente $3,5 \%$ de plantas visitadas.

Apesar da técnica do azul de metileno ser bastante simples e rápida, os dados obtidos devem ser considerados como uma estimativa do percentual de plantas visitadas por insetos, polinizadores ou não. Deste modo, não deve ser descartada a utilização de métodos que usem marcadores genéticos na aferição do percentual de plantas cruzadas.

O azul de metileno quando seca forma uma película pulverulenta que é mais clara e seca do que o pólen do algodão e tem partículas menores e mais numerosas e, por isto é, mais facilmente distribuído através das plantas (Thies, 1953). Este método seria mais útil se uma relação fixa pudesse ser estabelecida entre a distribuição de partículas de azul de metileno e cruzamento entre plantas (Free, 1993).

Quatro locais (Serra da Petrovina I e II, Pedra Preta I e II) apresentaram amplitude de variação bastante alta $e$, consequentemente, maiores valores de desvio padrão e variância. Os locais Primavera do Leste e Campo Verde apresentaram médias e variâncias bastantes inferiores aos valores observados aos demais locais. 
A variação encontrada entre locais certamente é explicada pela atividade diferencial dos insetos polinizadores, que apresentam hábitos definidos de locomoção e distanciamento da colméia (Free, 1993). Assim, a localização das plantas avaliadas em relação ao "caminho" preferencial das abelhas pode ser um fator determinante nos valores de cruzamento encontrados.

A elevada amplitude de variação na taxa de cruzamento natural do algodoeiro, tanto entre plantas de um mesmo local e entre diferentes locais, é relatada por vários autores. Nos EUA, observou-se variação de $5 \%$ a $75 \%$, conforme a região (Finkner, 1954; Simpson \& Duncan, 1956; Pohelman, 1959).

Tabela 6 Taxa de cruzamento (\%) em seis locais: número de observações (N), média, taxa mínima (Min.) e máxima (Max.), amplitude (Ampl.), Desvio Padrão $(\sigma)$, Variância $\left(\sigma^{2}\right)$

\begin{tabular}{lccccccc}
\hline \multicolumn{1}{c}{ Local } & N & Média & Min. & Max. & Ampl. & $\sigma$ & $\sigma^{2}$ \\
\hline Pedra Preta I & 12 & 68,83 & 12,76 & 100,00 & 87,23 & 29,05 & 843,90 \\
Pedra Preta II & 10 & 50,44 & 0 & 100,00 & 100,00 & 38,43 & 1477,00 \\
Serra Petrovina II & 19 & 46,85 & 0 & 100,00 & 100,00 & 44,41 & 1972,85 \\
Serra Petrovina I & 13 & 44,98 & 0 & 100,00 & 100,00 & 46,25 & 2139,95 \\
Primavera Leste & 25 & 8,42 & 0 & 29,26 & 29,26 & 2,74 & 7,55 \\
Campo Verde & 28 & 6,54 & 0 & 32,89 & 32,89 & 2,79 & 7,81 \\
\hline \hline
\end{tabular}

Considerando as taxas de cruzamento encontradas (Tabela 6) concluí-se que esta espécie comportou-se como alógama em Pedra Preta, intermediária na Serra da Petrovina e quase-autógama em Campo Verde e Primavera do Leste. Em média $(t=29,68 \%), ~ o$ algodoeiro mostrou ser uma espécie intermediária, ou seja, com sistema reprodutivo misto. Entretanto, sua condução como espécie preferencialmente autógama ou alógama vai depender das interações da espécie com o ambiente em que for conduzida. Essa composição 
distingue 0 algodoeiro das espécie autógamas e alógamas, e acarreta conseqüências genéticas particulares.

O valor $\boldsymbol{x}^{2}=3444,34$ altamente significativo (Tabela 7) indicou uma forte dependência entre taxa de cruzamento e local. A análise dos contrastes ortogonais entre locais (Tabela 8 ) evidenciou semelhança entre as regiões de Pedra Preta e Serra da Petrovina, locais estes com as maiores taxas de cruzamento; todavia, ocorreram diferenças significativas entre os dois locais avaliados em Pedra Preta. O contraste de maior significância ocorreu entre regiões com alta e baixa taxa de cruzamento. Campo Verde e Primavera do Leste, locais onde foram observadas as menores taxas de cruzamento, apresentaram significância a $5 \%$ de probabilidade.

De acordo com o mapa (Figura 4) é possível verificar a proximidade entre os locais que apresentaram maior taxa de cruzamento, relativamente àqueles que apresentaram as menores taxas. As características ecológicas de cada região podem ser a causa da variação encontrada na taxa de cruzamento.

As áreas avaliadas em Pedra Preta são regiões onde existem uma grande predominância de vegetação nativa e as lavouras são em sua maioria de pequenos produtores. Nas propriedades avaliadas havia grande número de espécies polinizadas por insetos, pertencentes aos gêneros Cucurbita, Mangifera, Citrus, Coffea, Phaseolus, instaladas numa área relativamente pequena. As taxas de cruzamento encontradas em pequenas áreas são geralmente maiores do que as encontradas em áreas mais extensas (Poehlman, 1959). Outro fator determinante da alta taxa de cruzamento encontrada, foi a baixa utilização de inseticidas nos dois locais de Pedra Preta, o que favorece a proliferação dos insetos polinizadores. De acordo com Simpson \& Duncan (1953), a polinização depende mais da ação de insetos polinizadores do que de outros fatores. A diferença significativa observada entre os dois locais avaliados em Pedra Preta, provavelmente são decorrentes do posicionamento dos experimentos em relação à colméia. Sendo a maior taxa 
decorrente da maior atividade das abelhas que normalmente ocorre em áreas mais próximas da colméia (Simpson \& Duncan, 1956).

Tabela 7 Teste de independência entre taxa de cruzamento e locais: número de sementes com glândulas (CG), e sem glândulas (SG), suas respectivas freqüências observadas e esperadas e cálculo de quiquadrado $\left(x^{2}\right)$.

\begin{tabular}{|c|c|c|c|c|}
\hline $\begin{array}{l}\text { Locais } \\
\end{array}$ & Frequência & CG & SG & Total \\
\hline \multirow[t]{3}{*}{ Campo Verde } & Observada & 181,00 & 2881,00 & 3062,00 \\
\hline & Esperada & 1053,73 & 2008,26 & \\
\hline & $(f o-f e)^{2} / f e$ & 722,82 & 379,26 & \\
\hline \multirow[t]{3}{*}{ Serra da Petrovinal } & Observada & 1486,00 & 1155,00 & 2641,00 \\
\hline & Esperada & 908,85 & 1732,14 & \\
\hline & $(\text { fo-fe })^{2} / \mathrm{fe}$ & 366,49 & 192,30 & \\
\hline \multirow[t]{3}{*}{ Serra da Petrovinall } & Observada & 1372,00 & 945,00 & 2317,00 \\
\hline & Esperada & 797,35 & 1519,64 & \\
\hline & $(\mathrm{fo}-\mathrm{fe})^{2} / \mathrm{fe}$ & 414,13 & 217,29 & \\
\hline \multirow[t]{3}{*}{ Primavera do Leste } & Observada & 214,00 & 2301,00 & 2515,00 \\
\hline & Esperada & 865,49 & 1649,50 & \\
\hline & $(f o-f e)^{2} / f e$ & 490,40 & 257,31 & \\
\hline \multirow[t]{3}{*}{ Pedra Preta I } & Observada & 552,00 & 316,00 & 868,00 \\
\hline & Esperada & 298,70 & 569,29 & \\
\hline & $(f o-f e)^{2} / f e$ & 214,78 & 112,69 & \\
\hline \multirow[t]{3}{*}{ Pedra Preta II } & Observada & 401,00 & 418,00 & 819,00 \\
\hline & Esperada & 819,00 & 281,84 & \\
\hline & $(f o-f e)^{2} / f e$ & 50,37 & 26,43 & \\
\hline \multirow[t]{2}{*}{ Total } & Observado & 4206,00 & 8016,00 & 12222,00 \\
\hline & $x^{2}$ & & & $3444,34^{\star \star}$ \\
\hline
\end{tabular}


Tabela 8 Teste de $x^{2}$ para cinco contrastes ortogonais entre locais para taxa de cruzamento.

\section{Contrastes}

$x^{2}$

1. (Campo Verde+Primavera Leste) Vs

(Serra da Petrovina I + Serra da Petrovina II + Pedra Preta I + 3394,74** Pedra Preta II)

2. Campo Verde Vs Primavera do Leste $14,15^{*}$

3. (Serra da Petrovina I + Serra da Petrovina II) Vs (Pedra Preta I + Pedra Preta II) $0,68^{\text {ns }}$

4. Serra da Petrovina I Vs Serra da Petrovina II $4,39^{\text {ns }}$

5. Pedra Preta I Vs Pedra Preta II $36,70^{\star \star}$

Obs.: ns: não significativo pelo teste $\overline{x^{2}}$ a $1 \%$ e $5 \%$ de probabilidade.

*: significativo pelo teste $x^{2}$ a $5 \%$ de probabilidade.

**: significativo pelo teste $x^{2}$ a $1 \%$ de probabilidade.

No alto da Serra da Petrovina predomina a agricultura de alta tecnologia, com emprego de grande quantidade de inseticidas. Em tal circunstância, esperava-se que a taxa de cruzamento fosse baixa, em virtude da toxidez causada pelos inseticidas utilizados no período de floração do algodoeiro, sobre as abelhas. Neste período são utilizados inseticidas fosforados e carbamatos, que possuem uma ação tóxica muito elevada para abelhas, principalmente no dia da aplicação (Estesen et al., 1992). Deste modo, a ocorrência de cruzamento deve estar provavelmente associada à alta população de insetos polinizadores. Neste local, os plantios mais extensivos tiveram inicio na safra 97/98. Deste modo, espera-se que a taxa de cruzamento diminua gradualmente através das safras subsequentes, já que a mesma tende a diminuir a cada ano devido ao aumento da utilização de inseticidas nas lavouras de algodão (EUA, 1971). Este aumento da utilização de inseticidas é decorrente do aumento da incidência de diferentes insetos pragas na cultura do algodoeiro a partir do segundo ano consecutivo de plantio. 
Campo Verde e Primavera do Leste também são áreas onde os agricultores utilizam alta tecnologia na condução das lavouras. Os baixos valores encontrados de taxa de cruzamento, provavelmente foram devido à baixa atividade de insetos polinizadores, já que o manejo das áreas experimentais foi efetuado de maneira similar ao da Serra da Petrovina. Nestes dois municípios, o algodoeiro já é uma espécies cultivada há mais de quatro anos em áreas bastante extensas. O cultivo consecutivo do algodoeiro com crescente ocorrência de pragas e conseqüente aplicação de inseticidas, pode ter diminuído a população de insetos polinizadores, nestes dois municípios.

Nos EUA, a taxa de cruzamento detectada nos anos 50 e 60 eram altas, porque as lavouras ocupavam áreas restritas e ainda havia muita vegetação natural. Porém, nestes mesmos locais, a partir do anos 70 , só foram detectadas taxas inferiores a $5 \%$, o que torna o sistema reprodutivo da cultura do algodoeiro, essencialmente autógamo (EUA, 1971).

Em estudo desenvolvido no Estado de Arizona, EUA, para determinar os fatores responsáveis para os vários níveis de cruzamento encontrados em diferentes áreas, concluiu-se que as condições climáticas tiveram grande interferência, delimitando o período em que as abelhas efetuavam a coleta de pólen (Waller et al. 1986). Em trabalho desenvolvido entre os anos $1986 \mathrm{e}$ 1988, no México, a maior taxa de cruzamento observado no ano de 1988 em relação aos demais, foi associada ao aumento da população de abelhas (Loper \& Danka, 1991).

O estudo da taxa de cruzamento entre os diferentes genótipos utilizados, não foi possível devido à necessidade de controle total sobre a introdução de agentes polinizadores na área, ou através de plantio alternado dos genótipos na mesma fileira. Como o objetivo principal foi o de observar a taxa de cruzamento natural das áreas, a introdução de colméias ou insetos polinizadores de maneira artificial, inviabilizaria este estudo. Em condições naturais, o estudo entre diferentes genótipos fica limitado devido à localização das parcelas em relação às colméias e ao caminho preferencial das abelhas (Free, 1993). 
Segundo Brown (1958), as diferenças encontradas entre genótipos podem ser causadas pela atratividade de cada material aos insetos. Entretanto, Stephens \& Finkner (1953), demonstraram que maiores diferenças são detectadas entre espécies ( $G$. herbaceum e $G$. hirsutum) do que entre genótipos da mesma espécie. Em trabalho similar, Johannson (1959) demonstrou que as diferenças encontradas são devidas principalmente à estrutura floral das diferentes espécies.

Como os estudos foram efetuados em campos de variedades não relacionadas geneticamente, isto é, as progênies não eram provenientes da mesma mãe para serem consideradas como uma população, não pode ser estimado o coeficiente de endogamia $(F)$. Entretanto, nas populações com sistema misto de reprodução, as plantas apresentam diferentes coeficientes de endogamia e, consequentemente, diferentes taxas de autofecundação natural, isto é, estas populações são formadas de indivíduos autofecundados na proporção"s" e cruzados na proporção $t=1-s$ (Wright \& Cockerham, 1985).

Como o sistema de endogamia nas espécies de sistema misto é irregular (varia de uma planta para outra), a depressão por endogamia e a presença de carga genética poderá ser observada em proporções menores do que as observadas para alógamas. Neste caso em específico estas características não devem influenciar a viabilidade da espécie já que a mesma apresenta uma taxa bastante variável de autofecundação e, por conseqüência, elevada variação na endogamia por geração.

Os dados obtidos são referentes a somente uma geração. Entretanto, mesmo se o valor de " $s$ " (taxa de autofecundação natural) mantiver-se constante através das gerações, existe uma alteração no coeficiente de endogamia de uma geração para outra de forma crescente. Embora esta endogamia aumente, a probabilidade de encontrar uma planta com autofecundações sucessivas desde a primeira geração até a geração "t" diminui progressivamente. Este resultado é perfeitamente entendido já que existe uma dificuldade muito maior de se encontrar uma planta que provém de cinco 
gerações de autofecundação do que uma que provém de apenas duas autofecundações. Através destas considerações, pode-se prever, por exemplo, que durante a seleção do algodoeiro, quando acompanhada de endogamia completa (autofecundação artificial), ocorrerá um aumento do coeficiente de endogamia a cada geração.

Em muitas espécies de plantas nas quais a reprodução é efetuada tanto por cruzamento quanto por autofecundação, a contribuição destes dois tipos de sistema reprodutivo, varia de uma geração para outra de acordo com as condições ambientais e climáticas (Bennet \& Binnet, 1956).

O conhecimento da taxa de cruzamento do algodoeiro é primordial para o estabelecimento da metodologia a ser utilizada no programa de melhoramento. A elevada ocorrência de insetos polinizadores, torna imprescindivel a implantação de campos de autofecundação para manutenção da pureza genética das linhagens.

Segundo Gridi- Papp ${ }^{5}$, em locais onde a taxa de cruzamento é inferior a $5 \%$, não há necessidade de se efetuar o amarrío de flores em campos de autofecundação, tornando menos oneroso os custos de implantação do programa de melhoramento, além de possibilitar a avaliação de um maior número de linhagens. A instalação de campos de autofecundação também é efetuada nos locais onde a taxa de cruzamento é desconhecida.

Com base na literatura e nos dados obtidos, fica evidente que o algodoeiro pode comportar-se como autógama, alógama ou mista em função de fatores ambientais, o que irá refletir na seleção de genótipos superiores.

Os resultados obtidos permitem as seguintes recomendações:

a) A determinação constante da taxa de cruzamento natural nos programas de seleção, para aferir a sua flutuação. Isso levará a uma melhor interpretação da estrutura genotípica das populações em seleção;

b) A identificação de regiões e de técnicas que favoreçam a maior e a menor taxa de cruzamento natural. 


\subsection{Distância e direção da dispersão de pólen}

As médias obtidas em seis diferentes raios de dispersão, submetidas a análise de regressão (Figura 12), forneceram uma equação exponencial que indica uma tendência de decréscimo de $0,2351 \%$ de cruzamento a cada intervalo de distanciamento do centro de dispersão de pólen. O coeficiente de determinação $\left(r^{2}=0,9852\right)$ obtido foi altamente significativo. Os dados estimados pela curva de regressão, traçada através da equação, foram compativeis com os dados observados.

Os valores obtidos variaram de um máximo de $15,75 \%$ de cruzamento obtido no intervalo de zero a três metros de distância do ponto de dispersão de pólen até, um mínimo de $1,04 \%$ de cruzamento em distância superior a 10 metros. Através dos dados obtidos pode-se afirmar que, em tais condições, as plantas localizadas a 10 metros de outros genótipos sofreriam uma contaminação de aproximadamente $1 \%$ através do fluxo de pólen, sem utilização de barreiras vegetais.

Num experimento similar, Afzal \& Khan (1950) obtiveram maior contaminação até 3,8 metros do centro da área, sendo bastante esporádica o cruzamento além desta distância e não ocorrendo além de 30,5 metros. $\mathrm{Na}$ Austrália, Mungomery \& Glassop (1969) relatam um decréscimo de 1,7 a 0,1\% de cruzamento até 21 metros de distância das plantas marcadas. Estes dados concordam com os obtidos por Trought ${ }^{6}$ (citado por Free, 1993), que descreve em seu trabalho um decréscimo de $0,9 \%$ até dois metros de distância do centro de dispersão de pólen e $0,1 \%$ a 22 metros de distância.

\footnotetext{
${ }^{5}$ GRIDI-PAPP, I. L. (imregp@mpc.com.br.), Comunicação pessoal, 1998.

${ }^{6}$ TROUGHT, T. Notes on certain facts on vicinism and artificial pollination in Egypt. Empire Cotton Growing Review, v.7, p 13-18, 1930.
} 


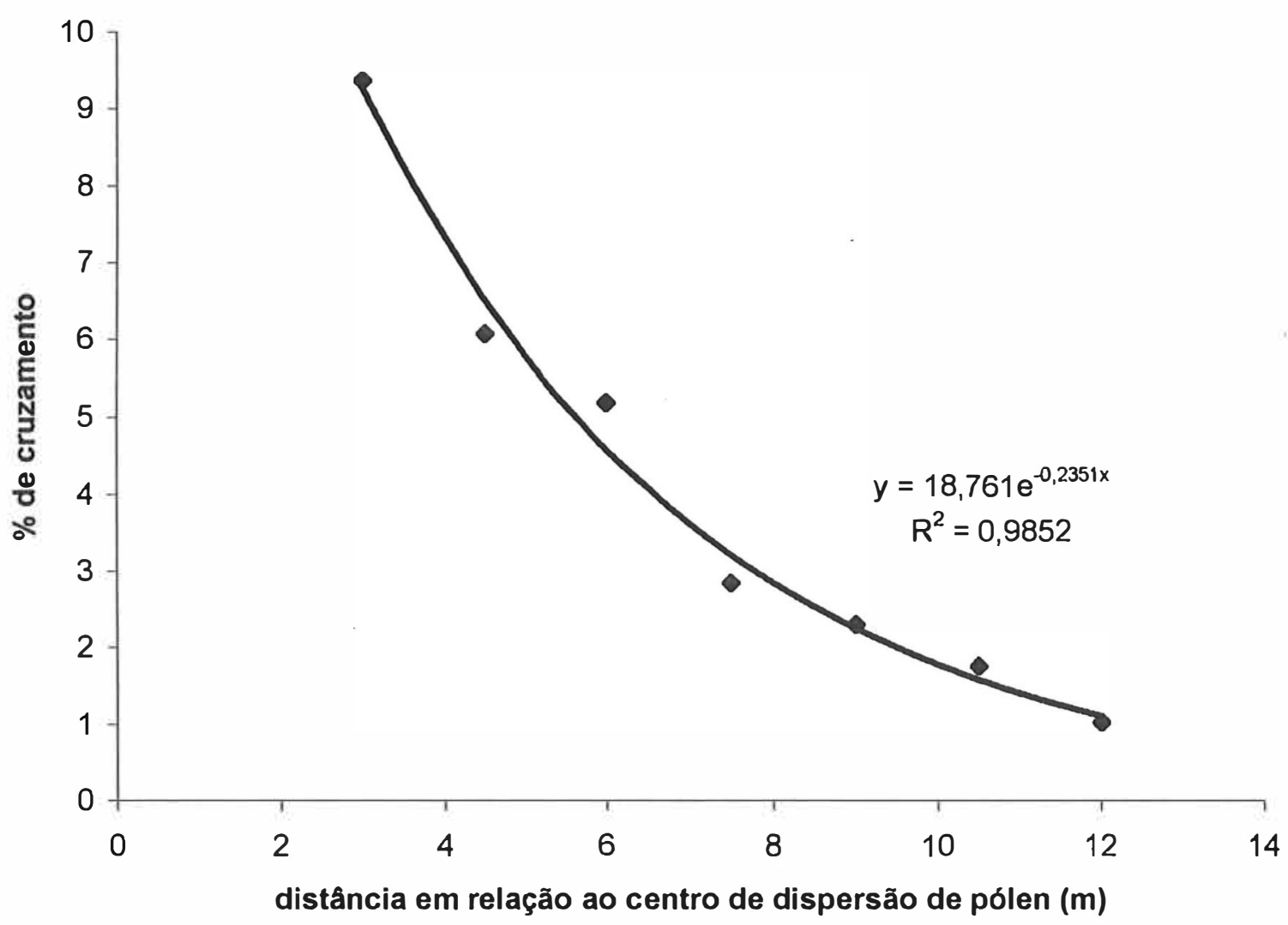

Figura 12 Relação entre o percentual de cruzamento $(Y)$ e o distanciamento do centro de dispersão de pólen (X).

Na mesma área foi aferido o percentual de plantas visitados por insetos polinizadores. A análise de regressão, mostrou uma equação de natureza potencial, com tendência de decréscimo de $0,2351 \%$ a cada intervalo de distanciamento da região central do campo (Figura 13). O coeficiente de determinação $\left(r^{2}=0,8953\right)$ foi altamente significativo, indicando que os pontos estimados pela equação utilizada concordam com os dados biológicos obtidos.

Em trabalho similar Sidhu \& Singh (1961), encontraram percentagens de flores visitadas por insetos decrescentes com o aumento da distância em relação ao ponto de dispersão. Estes valores variaram de $48 \%$ a seis metros 
até $2 \%$ a 16,7 metros. Em Uganda, Weatherley ${ }^{7}$ (citado por Free, 1993) relata que o percentual de cruzamento foi de $26,2 \%$ a $0,9 \mathrm{~m}, 3,2 \%$ a $15,5 \mathrm{~m}, 2,7 \%$ a $64 \mathrm{~m} \mathrm{e} 2,7 \%$ a $128 \mathrm{~m}$.

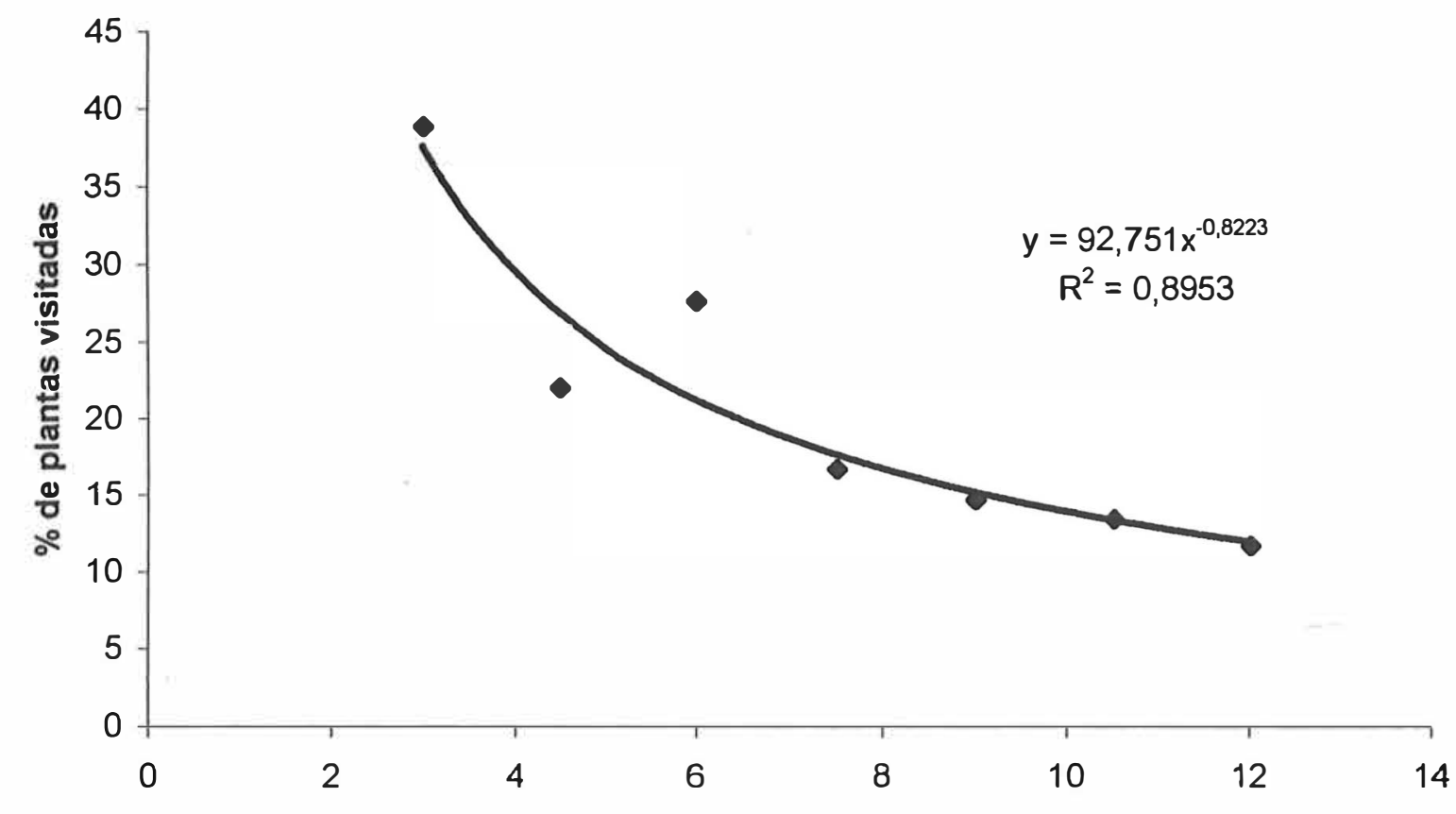

Distância em relação ao centro de dispersão de pólen (m)

Figura 13 Relação entre o percentual de plantas visitadas por insetos polinizadores $(Y)$ e diferentes distâncias em relação ao centro de dispersão de pólen $(X)$.

A dispersão do pólen através de insetos obedece a uma distribuição leptocúrtica ${ }^{8}$, um modelo que é comum à maioria dos movimentos bióticos (Handel, 1983). A leptocurtose da distribuição zoófila do pólen é composta pelo agrupamento e distribuição aleatória das plantas, assim como pelo padrão de inflorescência da maioria das plantas visitadas (Richards, 1997). Tal fato foi

\footnotetext{
7 WEATHERLEY, P. E. Uganda: Serere Area progress report. Program Report of Experimental Station of Empire Cotton Grow Corporation, 1944/45, p. 72-77, 1946.

${ }^{8}$ Curtose é o grau de achatamento de uma distribuição, considerado usualmente em relação a uma distribuição normal. A distribuição que tem um pico relativamente alto é denominada leptocúrtica. (Spiegel, 1993).
} 
observado tanto para a taxa de cruzamento quanto para como o percentual de plantas visitadas. Além das características das plantas visitadas, cita-se ainda que 90 a $99 \%$ dos vôos das abelhas, são efetuados entre plantas localizadas a pequenas distâncias, com o objetivo de fugir de predadores ou retornar à colméia, reforçando a hipótese de distribuição leptocúrtica (Richards, 1997).

Os dados referentes à taxa de cruzamento e percentual de plantas visitadas, foram correlacionados com $r^{2}=96,43 \%$. Este resultado demonstra que através da metodologia empregada para determinar o cruzamento, é possível obter uma correlação ótima entre estas variáveis.

Outra medida tomada neste ensaio foi a direção predominante de distribuição do pólen. Assim, os dados obtidos demonstraram que a maior concentração de cruzamento e percentual de plantas visitadas por insetos ocorreu na direção Norte e os menores valores foram observados na região Sul (Figuras 14 e 15); a correlação entre estas variáveis foi estimado em 96,94\%. O teste de independência entre a taxa de cruzamento e as direções cardeais (Tabela 9) obteve um valor de $\boldsymbol{x}^{2}$ altamente significativo $(517,85)$. Tal significância foi observada ainda entre os contrastes ortogonais estabelecidos (Tabela 10). Já o teste de independência entre o percentual de plantas visitadas e as direções (Tabela 11), foi observado um valor de $\boldsymbol{x}^{2} \quad$ significativo; os contrastes ortogonais calculados não detectaram significância entre as direções avaliadas (Tabela 12).

$\mathrm{Na}$ área submetida à avaliação, o vento predominante ocorreu no sentido Norte - Sul. A partir deste fato, era esperado que a maior concentração de cruzamentos fosse encontrada na porção sul da área avaliada. Entretanto, neste caso, a maior atividade dos insetos deve estar ligada ao distanciamento da colméia, não havendo grande interferência do sentido do vento. 


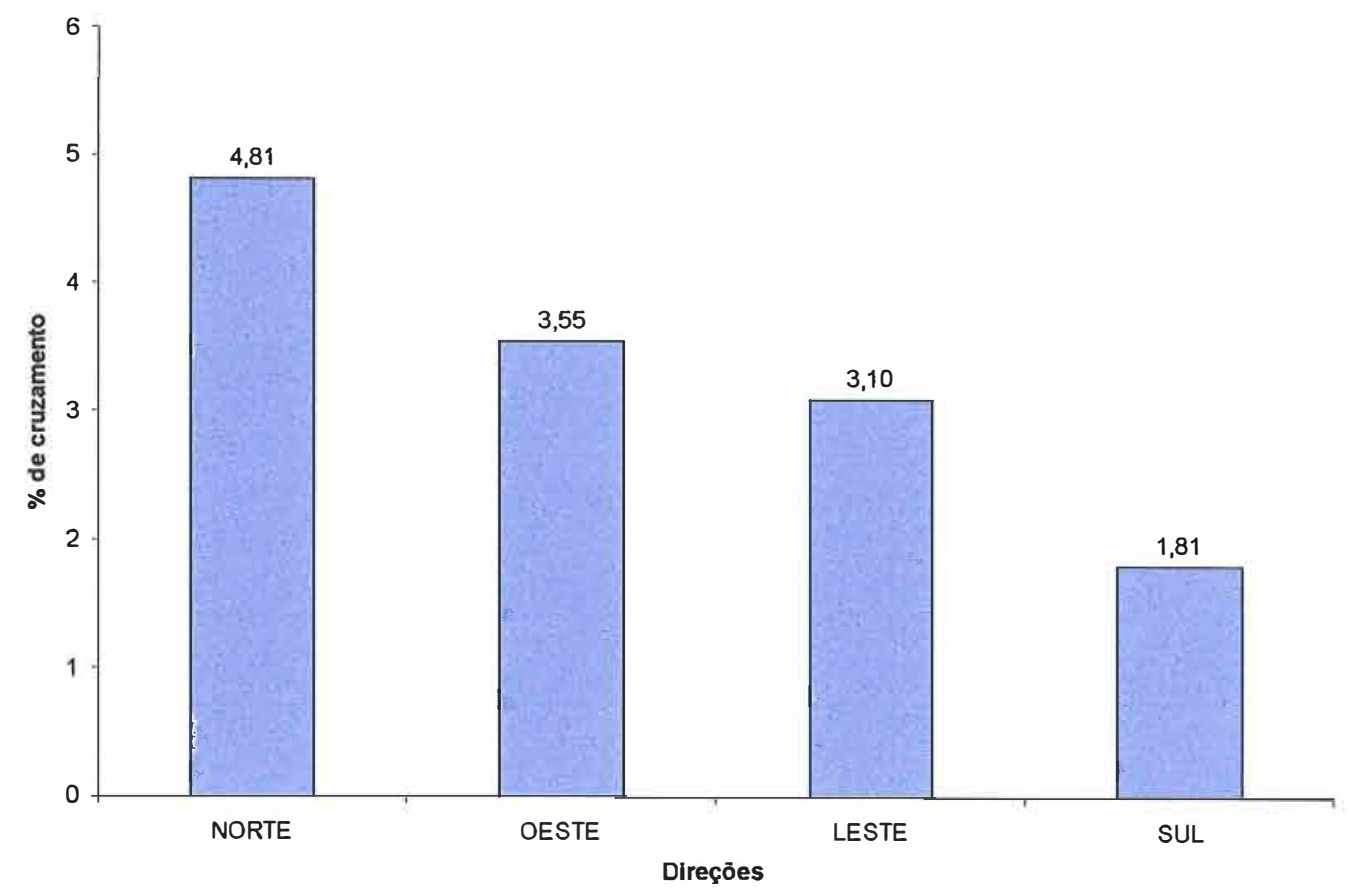

Figura 14 Taxa de cruzamento em diferentes direções cardeais.

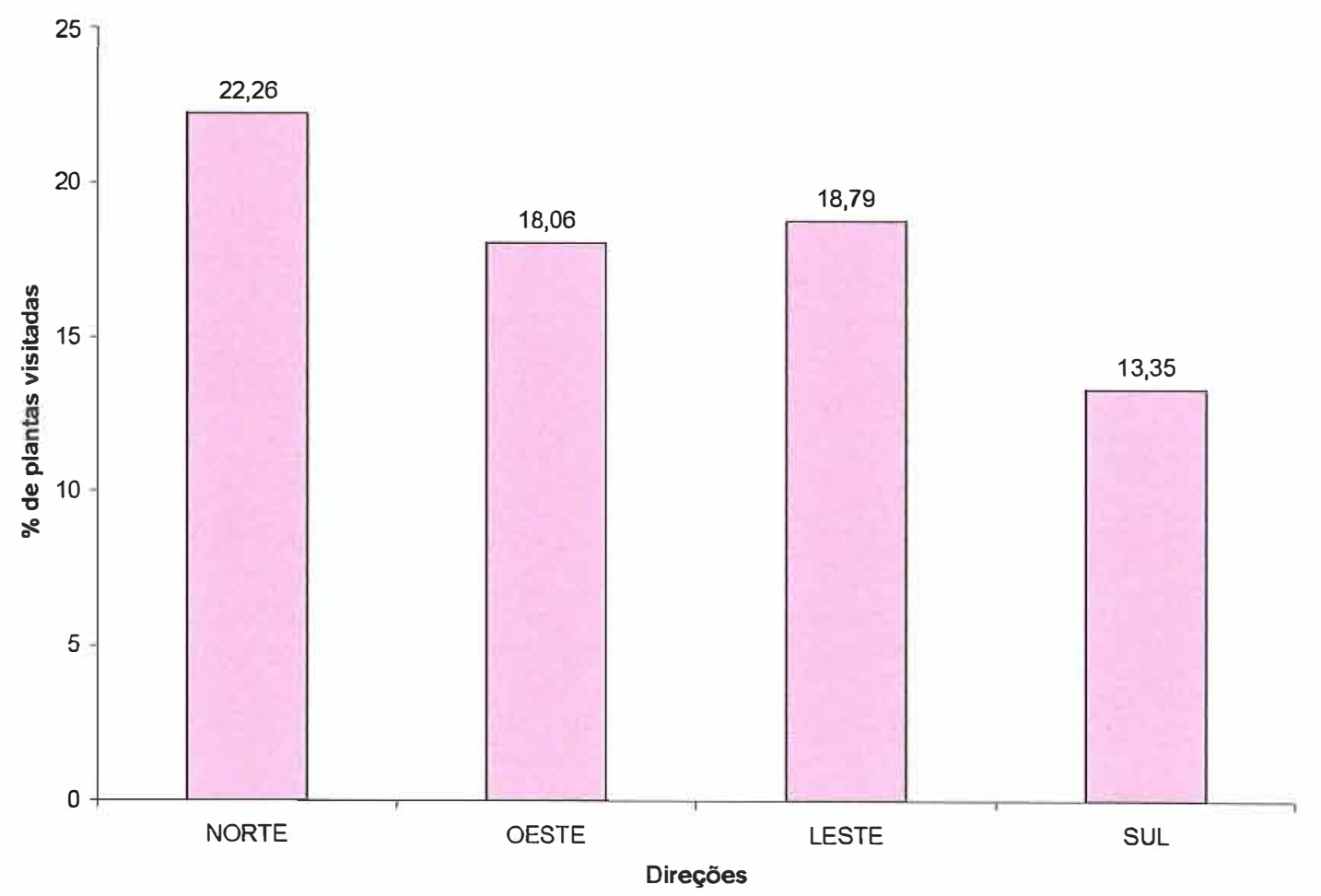

Figura 15 Percentual de plantas visitadas por insetos polinizadores em diferentes direções cardeais. 
Tabela 9 Teste de independência entre taxa de cruzamento natural e direções cardeais: número de sementes com glândulas (CG), e sem glândulas (SG), suas respectivas frequências observadas e esperadas e valores de qui-quadrado $\left(x^{2}\right)$.

\begin{tabular}{llrrr}
\hline \multicolumn{1}{c}{ Direções } & \multicolumn{1}{c}{ Frequência } & \multicolumn{1}{c}{ CG } & \multicolumn{1}{c}{ SG } & \multicolumn{1}{c}{ Total } \\
\hline Norte & Observada & 1596,00 & 31584,00 & 33180,00 \\
& Esperada & 1082,53 & 32097,47 & \\
& $\left(\right.$ fo-fe) ${ }^{2} / \mathrm{fe}$ & 243,55 & 8,21 & \\
\hline Oeste & Observada & 1272,00 & 34579,00 & 35851,00 \\
& Esperada & 1169,67 & 34681,33 & \\
& (fo-fe) ${ }^{2} / \mathrm{fe}$ & 8,95 & 0,30 & \\
\hline Leste & Observada & 1233,00 & 38597,00 & 39830,00 \\
& Esperada & 1299,49 & 38530,51 & \\
& (fo-fe) ${ }^{2} / \mathrm{fe}$ & 3,40 & 0,12 & \\
\hline Sul & Observada & 682,00 & 37058,00 & 37740,00 \\
& Esperada & 1231,30 & 36508,70 & \\
& (fo-fe) ${ }^{2} / \mathrm{fe}$ & 245,05 & 8,26 & \\
\hline Total & Observado & 4783,00 & 141818,00 & 146601,00 \\
& $\boldsymbol{x}^{2}$ & & & $517,85^{\star \star}$
\end{tabular}

**: significativo pelo teste $x^{2}$ a $1 \%$ de probabilidade.

Tabela 10 Teste de $x^{2}$ para três contrastes ortogonais para taxa de cruzamento entre diferentes direções cardeais.

\section{Contrastes}

$325,41^{\star *}$

1. Norte Vs (Sul + Leste + Oeste)

$253,85^{\star \star}$

2. Sul Vs (Oeste + Leste)

$12,06^{\star \star}$

3. Oeste Vs Leste

**: significativo pelo teste $x^{2}$ a $1 \%$ de probabilidade. 
Tabela 11 teste de independência entre percentual de plantas visitadas e direções cardeais: número de plantas visitadas (PV), e não visitadas (PNV), suas respectivas freqüências observadas $e$ esperadas e valores de qui-quadrado $\left(\boldsymbol{x}^{2}\right)$.

\begin{tabular}{|c|c|c|c|c|}
\hline Direções & Frequência & PV & PNV & Total \\
\hline \multirow[t]{3}{*}{ Norte } & Observada & 65,00 & 227,00 & \multirow[t]{3}{*}{292,00} \\
\hline & Esperada & 52,64 & 239,35 & \\
\hline & $(f o-f e)^{2} / f e$ & 2,89 & 0,63 & \\
\hline \multirow[t]{3}{*}{ Oeste } & Observada & 54,00 & 245,00 & \multirow[t]{3}{*}{299,00} \\
\hline & Esperada & 53,91 & 245,08 & \\
\hline & $(f o-f e)^{2} / f e$ & 0,0002 & 0,00003 & \\
\hline \multirow[t]{3}{*}{ Leste } & Observada & 65,00 & 281,00 & \multirow[t]{3}{*}{346,00} \\
\hline & Esperada & 62,38 & 283,61 & \\
\hline & $(f o-f e)^{2} / f e$ & 0,10 & 0,02 & \\
\hline \multirow[t]{3}{*}{ Sul } & Observada & 43,00 & 279,00 & \multirow[t]{3}{*}{322,00} \\
\hline & Esperada & 58,05 & 263,94 & \\
\hline & $(f o-f e)^{2} / f e$ & 3,90 & 0,85 & \\
\hline Total & $\begin{array}{l}\text { Observado } \\
x^{2}\end{array}$ & 227,00 & 1032,00 & $\begin{array}{r}1259,00 \\
8,43^{\circ}\end{array}$ \\
\hline
\end{tabular}

Tabela 12 Teste de $x^{2}$ para três contrastes ortogonais para percentual de plantas visitadas por abelhas entre diferentes direções cardeais.

\begin{tabular}{ll}
\hline \multicolumn{1}{c}{ Contrastes } & \multicolumn{1}{c}{$\boldsymbol{x}^{2}$} \\
\hline 1. Norte Vs (Sul + Leste + Oeste) & $4,60_{\mathrm{ns}}$ \\
2. Sul Vs (Oeste + Leste) & $3,99_{\mathrm{ns}}$ \\
3. Oeste Vs Leste & $0,056_{\mathrm{ns}}$
\end{tabular}

Obs.: ns: não significativos pelo teste de $x^{2}$ a $1 \%$ de probabilidade. 
A direção do vôo das abelhas entre as inflorescências é um importante componente do fluxo gênico (Richards, 1997). Segundo Mogford (1974) os vôos das abelhas podem ser distinguidos entre direções seqüenciais ou aleatórias. Em trabalhos desenvolvidos através das espécies Armeria maritima e Limonium vulgare, pôde ser concluído que a direção dos vôos são impostas pelas condições climáticas e topográficas. O vento quase sempre unidirecional na localidade onde o trabalho foi desenvolvido (Scolt Head Island, Norfolk, UK) provavelmente foi o fator principal para a direção seqüencial de polinização observada. Quando o vento é forte as abelhas preferem voar a favor do mesmo. Direções aleatórias provavelmente são impostas pela topografia do terreno, isto é, pelo geo-posicionamento das colméias em relação ao campo avaliado (Woodell, 1978).

Obviamente, tanto a unidirecionalidade seqüencial e a direcionalidade aleatória podem ocorrer conjuntamente. As abelhas podem possuir uma unidirecionalidade de vôo e o ambiente pode determinar em que direção o vôo será favorecido (Woodell, 1978).

\subsection{Isolamento de campos de pequeno aumento}

Neste ensaio, a Crotalaria junceae foi utilizada como barreira vegetal, a fim de se isolar um campo dos demais, evitando a contaminação através do fluxo de pólen efetuado pelas abelhas. A crotalária é uma barreira comumente utilizada no Brasil para isolamento de campos de sementes de algodão. Entretanto, não foi encontrada em literatura nenhuma menção à eficiência da mesma como barreira vegetal. Esta espécie possui flores amarelas, que necessitam da visita de insetos polinizadores, tanto para efetuar o cruzamento quanto para estimular a autofecundação. Quando a população de insetos polinizadores é baixa, apresenta pouca formação de sementes (McGregor, 1976). A utilização desta espécie como barreira por alguns programas de melhoramento é devido a coincidência entre o período de floração do 
algodoeiro e da crotalária. Castro et al. (1982) comparou quatro espécies como barreiras vegetais e concluiu que a melhor eficiência foi obtida pelo milho, sorgo, algodão e crotalária, respectivamente.

A média de cruzamento obtida no ensaio estabelecido junto aos campos de pequeno aumento foi de 4,5\%. Entretanto, este valor deve estar subestimado já que não se considerou neste caso o cruzamento intrapopulacional. No caso de campos de sementes, o cruzamento intrapopulacional não tem grande importância, desde que não haja grande quantidade de mistura entre as plantas. Como o campo avaliado possuía um tamanho reduzido ( $10 \times 10$ metros) não foi possivel estabelecer uma tendência da distância e direção da dispersão de pólen como no ensaio anterior. Os dados da análise descritiva demonstram um mínimo de zero e um máximo de $90 \%$ de cruzamento. Como pode ser observado na Figura 16, a maioria das plantas apresentaram cruzamento, embora a taxas relativamente baixas, já que a maior freqüência dos dados encontrados está entre 0 e $5 \%$. Entretanto, se esta taxa de cruzamento for mantida através das gerações, logo será perdida a identidade genética das linhagens conduzidas em tais condições. Embora 4,5\% seja um valor considerado baixo, deve-se considerar que este é um valor médio do campo estudado, e que em uma amostra aleatória de plantas ou sementes, poderia até ser obtido uma média maior, se as estruturas selecionadas fossem em sua maior parte provenientes de cruzamentos interpopulacionais. 


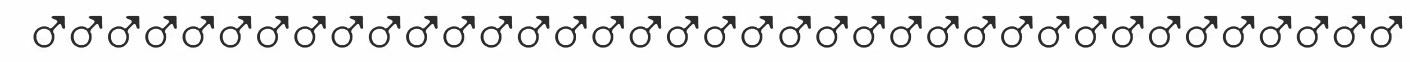

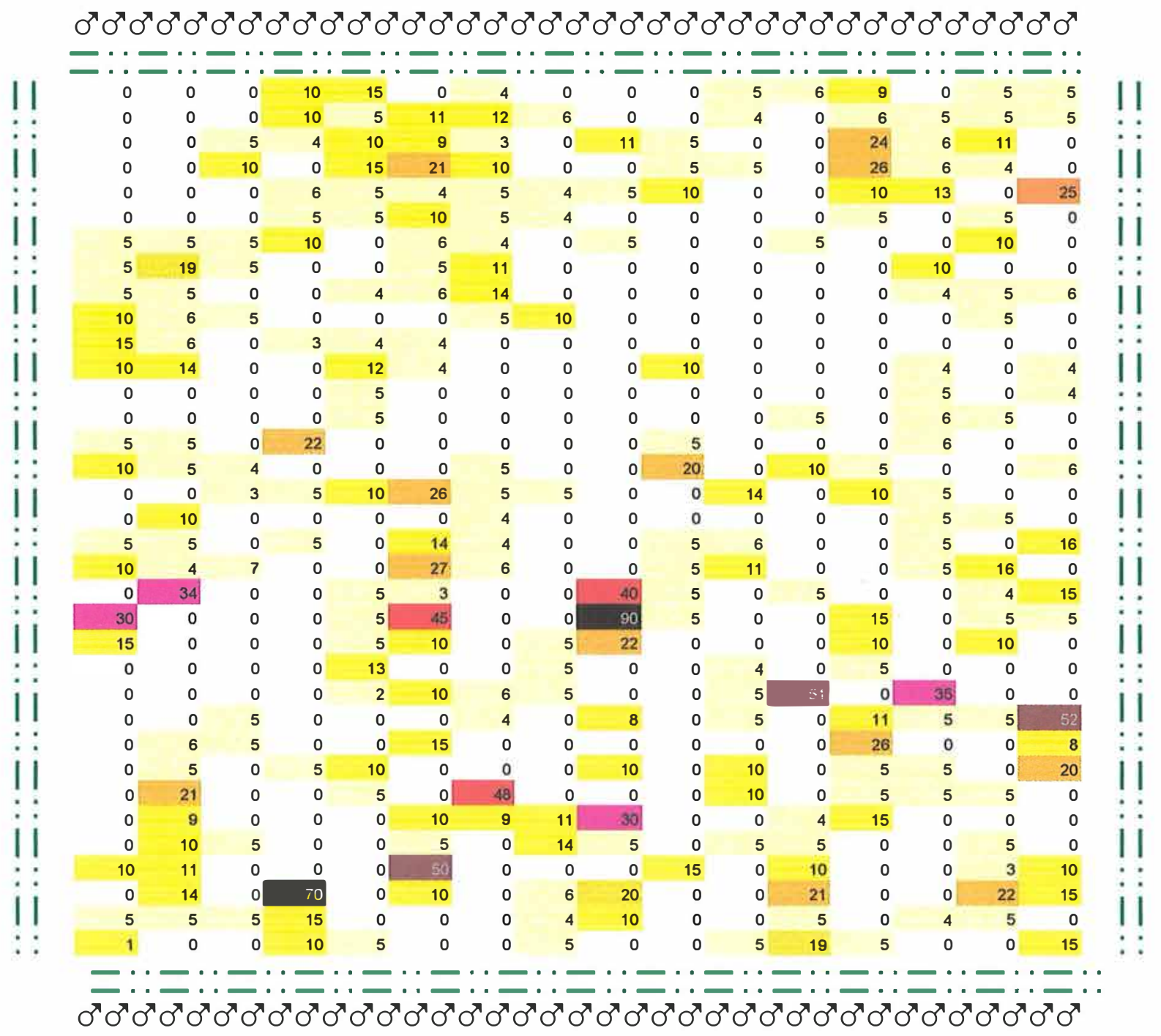

$\sigma^{x} \sigma^{x} \sigma^{x} \sigma^{x} \sigma^{x} \sigma^{x} \sigma^{x} \sigma^{x} \sigma^{x} \sigma^{x} \sigma^{x} \sigma^{x} \sigma^{x} \sigma^{x} \sigma^{x} \sigma^{x} \sigma^{x} \sigma^{x} \sigma^{x} \sigma^{x} \sigma^{x} \sigma^{x} \sigma^{x} \sigma^{x} \sigma^{x} \sigma^{x} \sigma^{x} \sigma^{x} \sigma^{x} \sigma^{x} \sigma^{x} \sigma^{x} \sigma^{x} \sigma^{x} \sigma^{x} \sigma^{x} \sigma^{x}$

Legenda:

\begin{tabular}{|c|c|c|c|}
\hline 0 & $0,1-9 \%$ & $10-19 \%$ & $20-29 \%$ \\
\hline $30-39 \%$ & $40-49 \%$ & $50-59 \%$ & $>60 \%$ \\
\hline
\end{tabular}

Figura 16 Esquema de dispersão de pólen no campo de pequeno aumento de linhagens. Os valores de cada casela representam o percentual de cruzamento de cada planta avaliada, com visualização facilitada pelo uso de cores diferentes. 
Aplicações de inseticidas eliminam ou reduzem significativamente a presença de abelhas dentro de uma área experimental mas não podem prevenir a migração das abelhas para reservas alternativas. $O$ único método prático e ecologicamente seguro sugerido para reduzir o intercruzamento entre campos é o uso de barreiras e adequado isolamento entre genótipos diferentes (Ellstrand \& Hoffman, 1990). Apesar do uso de barreira vegetal restringir a disseminação de pólen, a cultura que apresenta melhores resultados para esta finalidade é o próprio algodoeiro (Green \& Jones, 1953). As barreiras de algodoeiro servem como um depósito de pólen transportado por abelhas, e tem resultado num decréscimo de $20 \%$ de intercruzamento entre fileiras adjacentes até $1 \%$ entre fileiras distantes 10,8 metros. O uso de bordaduras em fileiras adjacentes aos campos de produção de sementes tem demonstrado maior eficiência em restringir o movimento de pólen do que quando a área entre os campos não é cultivada (Green \& Jones, 1953).

A idéia do uso de barreiras de outras espécies vegetais além do algodoeiro foi abandonada nos EUA, devido à extensiva pesquisa que demonstrou a sua ineficiência em evitar o cruzamento. Assim, a recomendação é de que uma distância mínima de 1,6 km seja tomada entre campos de diferentes genótipos (Pope et al., 1944) e que somente uma variedade seja produzida em cada localidade (Brow \& Ware, 1958).

O controle do cruzamento nesta cultura pode ainda ser obtido por métodos de autofecundação artificial das flores efetuada por meios mecânicos. Este método é necessário principalmente nos trabalhos de seleção de plantas em populações segregantes e na manutenção de coleções puras de germoplasma. Os métodos artificiais de autofecundação consistem, geralmente, no amarrío de botões florais, ou no seu enclausuramento através de sacos de papel ou pano, efetuados na véspera da abertura das flores (Penna et al., 1991). Esta técnica além de ser bastante onerosa, limita a capacidade de teste do programa de melhoramento. Além deste, fato a autofecundação das 
progênies através do amarrío de flores, tem baixo índice de pegamento nos períodos inicial e final da floração, dependendo também da habilidade da mãode-obra utilizada. Devido a estes fatores a produção de sementes através deste procedimento geralmente é muito baixa.

Segundo Castro et al. (1982), o fato do algodoeiro permitir a fecundação cruzada, por um lado é benéfica por que possibilita em termos de recombinação a variabilidade genética; por outro lado, é indesejável pelas possíveis contaminações em programas de manutenção e multiplicação de sementes de diferentes genótipos.

A seleção, $O$ incremento de semente genética e a manutenção de variedades são efetuadas sob cruzamento natural mas, freqüentemente, em condições de semi-isolamento, ou seja, os campos são isolados de outras variedades, permitindo-se, entretanto, a proximidade de genótipos aparentados (Poehlman, 1959; Gridi-Papp, 1969 e Lee, 1987).

Em estudos de Green \& Jones (1953), houve uma marcante redução da polinização cruzada com o aumento da distância da fonte de pólen. Obtiveram para a primeira fileira $19,5 \%, 6 \%, 2 \%$ e $0,6 \%$ de cruzamento entre campos, respectivamente distanciados a $0 \mathrm{~m}, 5 \mathrm{~m}, 10 \mathrm{~m}, 25 \mathrm{~m}$ e $50 \mathrm{~m}$. Mostraram também que a bordadura ou barreira com o próprio algodoeiro foi muito eficiente em reduzir o cruzamento natural, tendo sido obtidos valores de $19,5 \%, 3,8 \%$ e $1 \%$ de polinização cruzada para zero, cinco e nove fileiras adjacentes de barreiras de algodoeiro entre os dois estoques plantados. Baseados em dados de seus trabalhos e no bom senso, fizeram as seguintes recomendações para isolamento de campos: para a classe de sementes produzidas pelo melhorista, em campos de qualquer tamanho, deve-se eliminar 20, dez e zero fileiras bordaduras para aqueles plantados a menos de $50 \mathrm{~m}$, de 50 a 100m e acima de $100 \mathrm{~m}$ de distância, respectivamente. 


\subsection{Identificação de insetos polinizadores}

Entre os insetos encontrados visitando as flores do algodoeiro nos ensaios, foi caracterizado como principal agente polinizador a abelha Apis mellifera.

O cruzamento natural do algodoeiro é resultado quase que exclusivo da atividade de insetos, sendo as abelhas (Apoidea) os polinizadores mais expressivos (Thies, 1953, McGregor, 1976). Em Knoxville, Tennessee, o inseto polinizador de maior atividade foi a mamangava (Bombus spp.) (Simpson \& Duncan, 1956). Na Índia, as abelhas (Apis spp.) foram os polinizadores mais freqüentemente associados à cultura do algodoeiro (Sidhu \& Singh, 1961). No Brasil a abelha (Apis mellifera) foi considerada o polinizador de maior ocorrência natural associada à cultura (Silva et al, 1973).

\subsection{Avaliação da população de plantas sem glândulas}

Mediante o estabelecimento da população em local isolado de outros genótipos, foi possivel observar se as plantas e sementes oriundas das mesmas apresentavam ausência total de glândulas. Após 15 dias da germinação foram encontradas aproximadamente $5 \%$ de plântulas com presença de glândulas, sendo estas desbastadas. A cultura foi avaliada nas demais fases de desenvolvimento, não sendo encontradas glândulas em nenhuma das estruturas avaliadas (folhas, pecíolos, hastes e maçãs). As sementes oriundas de autofecundação também não apresentaram pigmentos. Deste modo, as plantas sem a presença de pigmentos foram consideradas totalmente homozigóticas para os genes $\mathrm{gl}_{2}$ e $\mathrm{gl}_{3}$, conforme o descrito por McMichael (1954).

Excluída a possibilidade de que plantas totalmente sem glândulas, pudessem ser portadoras de algum gene dominante para este caráter, é possível afirmar que as sementes com glândulas oriundas das mesmas 
somente são encontradas mediante cruzamento com plantas com glândulas. Assim, os dados obtidos através deste método demonstram as condições reais de cruzamento natural de cada região. 


\section{CONCLUSÕES}

a) A taxa de cruzamento natural do algodoeiro foi muito influenciada pelo ambiente, tendo alcançando uma média geral de $29,68 \%$, com valores extremos de $6,54 \%$ a $68,83 \%$.

b) O principal fator ambiental determinante da taxa de cruzamento foi a presença de insetos polinizadores, identificado como sendo a abelha (Apis mellifera).

c) Outros fatores ambientais de influência sobre a taxa de cruzamento foram: anos agrícolas, locais de cultivo, época de colheita e direções cardeais. A influência destes fatores sobre a taxa de cruzamento mostrou-se indireta, pois afetariam antes a população e a ação de polinizadores.

d) Distâncias mínimas de dez metros foram suficientes para minimizar a dispersão de pólen entre campos adjacentes, sem o uso de barreiras vegetais para isolamento. (exceto plantas de algodoino). 


\section{REFERÊNCIAS BIBLIOGRÁFICAS}

AFZAL, M.; KHAN, A. H. Natural crossing in cotton in Western Punjad. 1. Natural crossing in contiguous plants and rows. Agronomy Journal, v. 42, p. 14-19, 1950.

ALLARD, H. A. Preliminary observations concerning natural crossing in cotton. American Breeders' Association Magazine, v. 6, p. 156-170, 1910.

BALLS, W. L. FREE, J. B. Insect pollination of crops. London, Academic Press, 1993. 684p.

BENNETT, J. H.; BINET, F. E.. Association between mendelian factors with mixed selfing and randon mating. Heredity, v.10, p. 49-55, 1956.

BERNINGER, E. Étude de l'allogamie du cotonnier a la station de Tikem. Cotton et Fibres Tropicales, v. 15, p. 14-22, 1960.

BROWN, H. B. Vicinism or natural crossing in cotton. Bulletin of Modern Agriculture Experimentation, v. 13, n. 2, p. 1134-1138, 1927.

BROWN, H. B.; WARE, J. O. Cotton. New York, McGraw-Hill, 1958.

BUFFET, M. Contribution a l'étude de l'allogamie du cotonnier. Coton et Fibres Tropicales, v. 15, p. 391-396, 1960. 
CARTER, F. L.; CASTILLO, A. E.; FRAMPTON, V. L.; KERR, T. Chemical composition studies of seeds of the genus Gossypium. Phytochemistry, v.5, p. 1103-1112, 1966.

CASTRO, E. M. de. Isolamento de parcelas de algodoeiro (G. hirsutum) por barreiras vegetais. Piracicaba, 1975. 75p. Dissertação (mestrado) - Escola Superior de Agricultura "Luiz de Queiroz", Universidade de São Paulo.

CASTRO, E. M. de; GRIDI-PAPP, I. L.; PATERNIANI, E. Eficiência de Barreiras vegetais no isolamento de parcelas de algodoeiro. Pesquisa Agropecuária Brasileira, v.17, n.8, p. 1155-1161, ago. 1982.

CAVALERI, P. A.; GRIDI-PAPP, I. L. Estudo da taxa de cruzamento natural no algodoeiro. Ciência e Cultura, v.15, n.5, p. 204, 1963.

COLLINGS, G. H.; WALLACE, R. W. The extent of vicinism in cotton at Clemson College. Journal of American Society of Agronomy, v.23, n.6, p.490-492, 1931.

COOBLEY, L. S. An introduction to the botany of tropical crops. London: Longmans, 1956, 457p.

COOK, O. F. Cotton improvement through type selection, Washington: USDA, 1932. 15p. (USDA. Bulletin, 302).

COOK, O. F. Improvements in cotton production. Washington: USDA, 1921. 12p. (USDA. Circular, 200).

CRISÓSTOMO, J. R. Avaliação da estrutura e do potencial genético de uma população de algodoeiro (G. hirsutm L.) parcialmente autógama. Piracicaba, 1989. 179p. Tese (Doutorado) - Escola Superior de Agricultura "Luiz de Queiroz", Universidade de São Paulo.

CROSS, J. E.; RICHMOND, T. R. The use of glandless seed to determine the amount of natural crossing in Gossypium hirsutum L. Agronomy Journal, v.51, p. 511-512, 1959. 
ELLSTRAND, N. C.; HOFFMAN, C. A. Hybridization as an avenue of escape for engineered genes. BioScience, v.40, p. 438-442, 1990.

ESTADOS UNIDOS DA AMÉRICA. Department of Agriculture. Cotton varieties planted 1967-1971. Memphis, U.S. Dept. Agr. Consumer and Market. Serv., Cotton Div., 1971. 32p.

ESTESEN, B. J.; BUCK, N. A.; WALLER, G. D. et al. Residual life and toxicity to honey bees (Hymenoptera: Apidae) of selected insecticides applied to cotton in Arizona. Journal of Economic Entomology, v.85, n.3, p.700-709, June 1992.

FINKNER, M. D. The effect of dual pollination in upland cotton stocks differing in genotype. Agronomy Journal, v.46, n.3, p. 124-128, 1954.

FIRKY, M. A. Natural cross polination in cotton in Egypt. Cairo: Royal Agriculture Society, 1931. 40p. (Royal Agriculture Society, Technical Section Bulletin, 18).

FRAMPTON, V. L.; PONS, W. A.; KERR, T. A comparasion of chemical properties of seeds of Gossypium species. Economic Botany, v.14, p. 197199, 1960.

FREE, J. B. The effect of flower shapes and nectar guides on the behavior of foraging honeybees. Behaviour, v. 37, p. 269-285, 1970.

FREE, J. B. Insect pollination of crops. London, Academic Press, 1993. 684p.

FRYXELL, P. A. Mode of reproduction of higher plants. Botanic review, v. 23, p. $135-233,1957$.

FRYXELL, P. A. Mode of reproduction of higher plants. Botanical Review. v.23, p. $135-233,1967$

FRYXELL, P. A. A redefinition of the tribe Gossypieae. Botanical Gazette, v. 129, p. $296-308,1968$. 
FRYXELL, P. A. A revised taxonomic interpretarion of Gossypium L. (Malvaceae). Rheedea, v2, p. 108-165, 1992.

GALAL, H. E.; ABOU EL-FITTOUCH, H. A.; MORSHED, G. Effect of direction and distance on cross pollination in Egyptian cotton (G. barbadense L.). Experimental Agriculture. v. 8, p. 67-71. 1972.

GREEN, J. M.; JONES, M. D. Isolation of cotton for seed increase. Agronomy Journal, v. 45, p. 366-368, 1953.

GRIDI-PAPP, I. L. Genética e melhoramento do algodoeiro. In: KERR, W. E. Melhoramento e genética. São Paulo, USP, 1969. cap. 5, p. 101-104.

GRIDI-PAPP, I. L.; FUZATTO, M. G.; CAVALERI, P. A. et al. Melhoramento do algodoeiro no Estado de São Paulo: obtenção das variedades IAC $R M_{3}$ IAC 16 e IAC 17. Bragantia, v. 43, p. 405-423, 1984.

GRIDI-PAPP, I. L; CIA, E.; FUZATTO, M. G. et al. Manual do produtor de algodão. São Paulo: Bolsa de Mercadorias \& Futuros, 1992. 158p.

GROUT, R. A. Honey bees make hybrid cotton possible. American Bee Journal, v.95, p. 10-11, 1955.

HANDEL, S. N. Pollination ecology, plant population structure, and gene flow, in pollination biology. New York: Academic Press, 1983. 329p.

HANNY, B. W.; BAILEY, J. C.; MERIDETH JUNIOR. Yellow cotton pollen suppresses growth of larvae of tabacco budworm. Enviromental Entomology, v.8, p.706-707, 1979.

JOHANNSON, T. S. K. Racking honey bees in cotton fields with fluorescent pingments. Journal of Economic Entomology, v. 52, p. 572-577, 1959.

KEARNEY, T. H. In: FREE, J. B. Insect pollination of crops. London: Academic Press, 1993. 684p.

KNIGHT, R. L.; ROSE, M. F. A new approach to the technique of cotton growing. Empire Cotton Growing Review, v. 31, p. 162-170, 1954. 
KOHEL, R. J.; LEWIS, C. F. Cotton. Madison: American Society of Agronomy Press, 1984. 605p.

KOTTUR, G. L. In: McGREGOR, S. E. Insect pollination of cultivated crop plants. Washington: U.S. Government Printing Office, 1976. 411p.

LEE, J. A. Genetical studies concerning the distribution of pigment glands in the cotyledons and leaves of Upland cotton. Genetics, v. 47, p. 131-142, 1980.

LEE, J. A. Cotton. In: FEHR, W. R. Principles of cultivar development. New York: Macmillan, 1987. cap. 2, p. 126-160.

LEEWELLYN, D.; FITT, G. Pollen dispersal from two field trials of transgenic cotton in the Namoi Valley, Australia. Molecular Breeding, v.2, n.2, p. 157166, 1996.

LI, C. C. Populations genetics. Chicago: University of Chicago Press, 1966. $366 \mathrm{p}$.

LOPER, G. M. Cotton pollen: avoidance and absence of gossypol. Journal of Economic Entomology, v.79, n.1, p. 103-106, Feb. 1986.

LOPER, G. M.; DANKA, R. G.. Pollination test with africanized honey bees in southern Mexico, 1986-88. American Bee Journal, v. 12, p. 191-193, mar. 1991.

LOPER, G. M.; MARTIN, A. Cotton. Auburn: Auburn University press, 1984, $10 \mathrm{p}$.

LUKERFAHR, M. J.; FRYXEL, P. A. Content of gossypol in plants belonging to genera related to cotton. Economic Botany, v. 21, p. 128-131, 1967.

LUKERFAHR, M. J. L.; NOBLE, L. W.; HOUGHTALING, J. E.. Growth and infestation of bollworms and other insects on glanded and glandless strains of cotton. Journal of Economic Entomology, v.59, p. 817-820, 1966. 
LUSAS, E. W; JIVIDEN, G. M. Glandless cottonseed: A review of the first 25 years of processing and utilization research. Journal of the American Oil Chemists Society, v. 64, n. 6, p. 839-854, 1987.

MANGUEIRA, O. B. Taxa de alogamia na cultura do algodão "mocó". Recife: IPA, 1971, 22p. (IPA Boletim Técnico, 50).

McGREGOR, S. E. Cotton-flower visitation and pollen distribution by honey bees. Science, v. 129, p. 97-98, 1959.

McGREGOR, S. E. Insect pollination of cultivated crop plants. Washington: U.S. Government Printing Office, 1976. 411p.

McMICHAEL, S. C. "Glandless" boll in upland cotton and its use in the study of natural crossing. Agronomic Journal. v.51, p. 385-396, 1954.

McMICHAEL, S. C. Combined effects of glandless gene $\mathrm{gl}_{2}$ and $\mathrm{gl}_{3}$ on pigment glands in the cotton plant. Agronomic Journal. v.52, p. 385-386, 1960.

MEREDITH, W. R.; BRIDGE, R. R. Natural crossing in cotton (Gossypium hirsutum L.) in the Delta of Mississippi. Crop Science, v.13, n.5, p. 551-552, 1973.

MEREDITH JUNIOR, W. R. Inbreeding depression of selected $F_{3}$ cotton progenies. Crop Science, v.19, p. 86-88, 1979.

MOFFET, J. O.; STITH, L. S.; SHIPMAN, C. W. Honey bees and the production of hybrid cotton seed on male-sterile plants. . American Bee Journal, v.119, p. 492-493, 1979.

MOFFET, J. O.; STITH, L. S.; BURKHARDT, C. C. et al. Fluctuation of wild bee and wasps visits to cotton flowers. Arizona Academy of Science, v.11, p. 64-68, 1976a.

MOFFET, J. O.; STITH, L. S.; BURKHARDT, C. C. et al. Insect visitors to cotton flowers. Arizona Academy of Science, v.11, p. 47-48, 1976b. 
MOFFET, J. O.; STITH, L. S.; BURKHARDT, C. C. et al. Nectar secretion in cotton flowers and its relation to floral visits by honey bees. American Bee Journal, v. 116, n.32, p. 34-36, 1976c.

MOGFORD, D. J. Flower colour polymorphism in Circium palustre. 2. Pollination. Heredity, v. 33, p. 257-263, 1974.

MUNGOMERY, V. E.; GLASSOP, A. J. Natural cross-pollination of cotton in Central Queensland. Journal of Animal Science, v.26, p. 69-74, 1969.

NOVEMBRE, A. D. da L. C. Estudo da metodologia para a condução do teste de germinação em sementes de algodão (Gossypium hirsutum L.) deslintadas mecanicamente. Piracicaba, 1994. 133p. Dissertação (Mestrado) - Escola Superior de Agricultura "Luiz de Queiroz" - Universidade de São Paulo.

PARKS, H. B. The cotton plant as a source of nectar. American Bee Journal, v. 61, n.12, p.24-27, 1921.

PEEBLES, R. H. Pure seed production of Egyptian-type cotton. Washington: USDA, 1942. 20p. (USDA, Circular, 646).

PENNA, J. C. V.; MIRANDA, A. R. de; SANTOS, E. O. dos. Controle artificial de Polinização em algodoeiro. Pesquisa Agropecuária Brasileira. v.26, n.3, p.347-352, mar. 1991.

PEREIRA, M. B.; VENCOVSKY, R.; FREIRE, E. C. Número de gerações necessárias para uma população de sistema reprodutivo intermediário atingir o equilíbrio. In: Reunião Anual da Sociedade Brasileira de Genética, 38., Curitiba, 1986. Resumos. Curitiba: SBPC, 1986.

POEHLMAN, J. M. Breeding field crops. New York: Henry Holt, 1959. 220p.

POPE, O. A.; SIMPSON, D. M.; DUNCAN, E. N. Effect of corn barriers on natural crossing in cotton. Journal of Agricultural Research, v.68, p. 347, 1944. 
QUEIROGA, V. de P.; MENEZES NETO, J.; MATOS, V. P. Determinação da taxa de dispersão do pólen, em algodoeiro arbóreo, com uso do azul de metileno. Revista Ceres, v.40, n.230, p. 413-417, 1993.

RAMALHO, M.; SANTOS, J. B. dos; PINTO, C. B. Genética na agropecuária. São Paulo: Globo, 1997. 359p.

RICHARDS, A. J. Plant breeding systems. 2 Ed. Cambridge, Chapman \& Hall, 1997. 529p.

RICHMOND, T. R. Effects of sodium 2,3-diclhroisobutyrate on six caracteristics of American upland cotton. Crop Science. v.2, p. 58-60, 1962.

SAPPENFIELD, W. P. Estimate of natural cross in upland cotton in Southeast Missouri. Crop Science. v.3, p.566. 1963.

SIDHU, A. S.; SINGH, S. Studies on agents of cross pollination of cotton. Indian Cotton Growing review, v. 16, p.18-23, 1961.

SILVA, F. P.; SANTOS, J. M. R.; MOREIRA, J. de A. N. Observações sobre os possíveis agentes de polinização natural do algodão "mocó" (Gossypium hirsutum marie galante, Hutch.) no Estado do Ceará, Brasil. Fortaleza: UFCE, 1973. 39p. ( Relatório Técnico, 4).

SIMPSON, D. M. Natural cross pollination in cotton. Washington: 1954. 17p. (USDA. Technical Bulletinm 1094).

SIMPSON, D. M.; DUNCAN, E. N. Effect of selecting within selfed lines on the yield and other characters of cotton. Agronomy Journal, v. 45, p. 305-308, 1953.

SIMPSON, D. M.; DUNCAN, E. N. Cotton pollen dispersal by insects. Agronomy Journal, v.48, p. 305-308, 1956.

SPIEGEL, M. R. Estatística. São Paulo: Makron Books, 1994, 639p.

STEEL, R. G. D.; TORRIE, J. H. Principles and procedures of statistics: a biometrical approach. New York: McGraw-Hill, 1980. 633p. 
STEPHENS, S. G.The composition of an open pollinated segregating cotton population. American Nature, v. 90, n. 850, p.257-269. 1956.

STEPHENS, S. G.; FINKNER, M. D. Natural crossing in cotton. Economic Botany. v.7, n.3, p. 257-269, 1953.

THIES, S. A. Agents concerned with natural crossing of cotton in Oklahoma. Journal of Agronomy, v.45, p. 481-484. 1953.

THOMPSON, N. J. Cotton varietiy trials in the Old Valley, Northwestern Australia. Empire Cotton Growing Review, v.43, n.1, p. 18-21, 1966.

TROUGHT, T. In: FREE, J. B. Insect pollination of crops. London: Academic Press, 1993. p. 364-367.

TURNER, J. H. Diferential response of cotton varieties to natural crossing. Agronomy Journal, v.45, p. 246-248. 1953.

UMBECK, P. F.; KENNETH, A. B.; NORDHEIM, E. V. et al. Degree of pollen dispersal by insects from a field test of genetically engineered cotton. Journal of Economic Entomology, v.84, n.6, p. 1943-1950, Dec. 1991.

WALLER, G. D.; LOPER, G. M.; BUCHMANN, S. L. Pollination research on hybrid cotton seed production. American Bee Journal. v. 63 , n. 12, p. 835, Dec. 1986.

WEATHERLEY, P. E. In: FREE, J. B. Insect pollination of crops. London: Academic Press, 1993. 684p.

WOODELL, S. R. J. Directionality in bumblebees in relation to environmental factors, in: Richards, $A, J$. The pollination of flowers by insects. London, Academic Press, 1978. p. 31-39,

WRIGHT, A. J.; COCKERHAM, C. C. Selection with partial selfing. I. Mass selection. Genetics, v. 109, p. 585-597, 1985. 
YU, C. P.; HSIEH, L. C. A discussion on the methods of studying the percentage of natural crossing in cotton. Journal of Agricultural of China. v. 160, n. 8 , p.1-16, 1937.

ZHANG-CHANGQING; LU-QUNYAN, WANG-ZHIXING, JIA-SHIRONG, ZHANG-CQ, LU-QY, WANG-ZX, JIA-SR. Frequency of 2,4D resistant gene flow of transgenic cotton. Scientia Agriculture Sinica, v.30, n.1, p.92-93, 1997.

ZUNINO, H. A. Percentage of free pollination in field of cotton. Informaciones de las Investigaciones Agricolas, v.2, n.24, p. 12. 1949. 


\section{APÊNDICE}


Número médio de flores encontradas em diferentes dias após a emergência (d.a.e.).

\begin{tabular}{cccccccc}
\hline d.a.e. & $\begin{array}{c}\text { CNPA } \\
\text { Antares }\end{array}$ & $\begin{array}{c}\text { BRS } \\
\text { FACUAL }\end{array}$ & $\begin{array}{c}\text { CNPA } \\
\text { ITA 90 }\end{array}$ & $\begin{array}{c}\text { CNPA } \\
\text { ITA 96 }\end{array}$ & $\begin{array}{c}\text { BRS ITA } \\
94-122\end{array}$ & $\begin{array}{c}\text { BRS ITA } \\
94-151\end{array}$ & $\begin{array}{c}\text { BRS ITA } \\
95-743\end{array}$ \\
\hline 27 & 0 & 0 & 0 & 0 & 0 & 0 & 0 \\
33 & 0 & 0 & 0 & 0 & 0 & 0 & 0 \\
40 & 0 & 0 & 0 & 0 & 0 & 0 & 0 \\
47 & 0 & 0 & 0 & 0 & 0 & 0 & 0 \\
54 & 0,5 & 3,00 & 0,25 & 0 & 0 & 0,75 & 0,25 \\
60 & 1,25 & 1,00 & 1,75 & 0,50 & 1 & 0,75 & 1,75 \\
69 & 0,75 & 3,00 & 1,50 & 0,75 & 1 & 0,5 & 1,75 \\
77 & 0,5 & 4,00 & 2,00 & 1,00 & 1 & 1,5 & 1,5 \\
84 & 1,5 & 1,00 & 2,00 & 2,75 & 1 & 1 & 2,5 \\
91 & 1,25 & 3,00 & 1,00 & 0,25 & 1 & 1,25 & 0,25 \\
97 & 2,75 & 3,00 & 2,75 & 1,00 & 0 & 1 & 1,25 \\
103 & 1,25 & 1,00 & 2,75 & 1,00 & 1 & 2,5 & 1,25 \\
109 & 0,5 & 1,00 & 1,25 & 0,75 & 2 & 1,5 & 1 \\
116 & 0 & 0 & 0,75 & 0 & 0 & 0,25 & 0 \\
123 & 0 & 0 & 0 & 0 & 0 & 0 & 0 \\
130 & 0 & 0 & 0 & 0 & 0 & 0 & 0 \\
141 & 0 & 0 & 0 & 0 & 0 & 0 & 0 \\
145 & 0 & 0 & 0 & 0 & 0 & 0 & 0 \\
\hline
\end{tabular}

